\title{
NEGOTIATION AND INCORPORATION ON THE MARGINS OF WORLD-SYSTEMS: EXAMPLES FROM CYPRUS AND NORTH AMERICA
}

\author{
P. Nick Kardulias \\ Department of Sociology and Anthropology \\ College of Wooster \\ pkardulias@wooster.edu
}

\begin{abstract}
As originally formulated, the world-systems model postulated a relationship in which core states exploited peripheries for raw materials and made the latter into dependent satellites. This approach views indigenous people in peripheries as passive recipients at the mercy of political and economic forces beyond their control. While in many cases the impetus for change was from cores to peripheries, there were certainly instances in which the margins actively (and occasionally successfully) resisted incorporation. At times, they also had the ability to select the precise form of their incorporation. While in many cases this did not alter the consequences for indigenous people, there were occasions when natives not only reacted successfully, but also outlined the terms of the encounter. This is a process that I call negotiated peripherality. Underlying this perspective is a biological analogy: just as biological populations experience the greatest change at the borders of their territories where the effects of gene flow are felt first and most dramatically, so too do cultural changes occur at an accelerated rate in contact zones. This paper explores the nature of negotiated change through two case studies. The archaeological example examines how ancient inhabitants of Cyprus selectively adopted features from the Near Eastern and Greek cultures for whose worldsystems the island served as a marginal periphery. The second example is an ethnohistoric study of how Native Americans managed the terms of their involvement in the fur trade with Europeans. Both cases demonstrate the active role of peripheral people as decision-makers.
\end{abstract}

\section{INTRODUCTION}

Various scholars pose several important questions concerning the nature of core-periphery interaction (Carlson 2001, 2002; Chase-Dunn and Hall 1997: 59-77). Some ask if the core-periphery construct is a useful one that illuminates intersocietal relations, what type of variation exists in this phenomenon, and if there are viable options to the hierarchical approach many have adopted in the past. I hold that the coreperiphery distinction is still a viable way to think about what happens when different groups come into contact. What we need to do is examine the multiple dimensions of this interaction, rather than assume one particular form of relationship. Clearly, the original world-systems model of Wallerstein (1974) paid too little attention to the active role of people on the peripheries (see Hall 1986). In this paper I use the concept of negotiated peripherality (Kardulias 1999; Morris 1999) to explore how groups on the margins of great civilizations take matters into their own hands. By this term I mean the willingness and ability of individuals in peripheries to determine the conditions under which they will engage in trade, ceremonial exchange, intermarriage, adoption of outside religious and political ideologies, etc. with representatives of expanding states. We have to keep in mind that the representatives of the core are on foreign turf, and 
their very presence (at least initially) is often on terms dictated by the natives. Therefore, the outsiders must negotiate the terms of their presence. This understanding may take the form of a contractual agreement, but can also be a fluid arrangement that meets particular needs under certain circumstances. Hall (1999) has pointed out that incorporation is a variable phenomenon. In the case of the North American fur trade (see below), the natives clearly held the upper hand in this process at the outset and had a major say in the terms of trade. This fact illustrates that even when the contact is between state and non-state societies, the hierarchical imperative of early world-systems formulations need not come into play. Native peoples have the option of accepting or rejecting symbolic as well as utilitarian objects (and practices, e.g., methods of food preparation). They can also alter objects and symbols as part of the process of adoption. Since the cultural divide runs both ways, we need to understand that core representatives also adapt their products and behavior in response to the demands of the natives; those who do not run the risk of losing a potentially lucrative market. In the premodern period it was a rare circumstance when a state could impose its will on a periphery in an unfettered manner, or if it did, the effects might not be long-lasting.

Because of the intriguing mixture of activities that comprised intersocietal interaction, the locations where such events occurred were areas of intense cultural ferment. Contact could take the form of violent confrontation, aggressive (but non-violent) displays to impress other parties, small scale barter, exchange of ritual objects, trade in practical commodities, mutual participation in rituals, and other events. Exchange involved both physical objects and information and certainly had an impact on both parties in the transaction. Such an admixture could easily stimulate changes in both groups through the processes of direct borrowing, adoption of new foods, and alteration of items or practices to fit the recipient group's interests and values. It would be at such core-periphery contact points that culture change would be at its most intense. I suggest that this situation is analogous to the process of gene flow. The greatest degree of genetic change tends to take place in the areas that border two breeding populations, or demes, because the admixture of individuals significantly increases the genetic variability (Park 2002: 76-77). Evolutionary biologists refer to such areas as hybrid zones (Futuyma 1986:115). Such genetic mixing, because it increases the size and diversity of the gene pool, is a vital mechanism in physical evolution. The archaeological and ethnohistoric records also indicate that core-periphery contact zones served a similar purpose, not only in terms of interbreeding, but also in the form of cultures being reshaped. The difference between the genetic and social forms of this contact is that the latter involves human motivation as a mechanism of change, as well as strictly biological processes.

Below I examine two examples of core-periphery contact in light of this model of negotiated peripherality. The first is on Cyprus where archaeological work has revealed a long-term process of adaptation between a rural area and surrounding polities (Figure 1). The second example deals with the incorporation of Native Americans into the fur trade. What this study indicates is the ability of worldsystems theory to explain a wide range of phenomena from different geographic regions and time periods. Revisions to Wallerstein's original model over the past three decades have expanded the boundaries of investigation beyond the origins of capitalism in the long sixteenth century. Some (e.g., Stein 1999) argue that loosening the chronological and spatial constraints in this manner alters worldsystems theory beyond recognition. Many others suggest the world-systems approach gains analytical and conceptual rigor by broadening its temporal and geographic horizons. Additional data from a variety of venues augmented evolutionary theory in the nineteenth and twentieth centuries. For example, while Darwin's notion of natural selection was a major breakthrough, he never figured out the specific mechanism of inheritance; subsequently, some viewed Mendelian genetics as an opposed paradigm, until the two ideas were merged in the New Synthesis. More recently, punctuated equilibrium has challenged certain aspects of gradualism, but without undermining the whole Darwinian edifice. In a similar manner, world-systems theory has been and should continue to be open to refinements that build on the original foundations. I view the concept of negotiated peripherality as one such effort. 


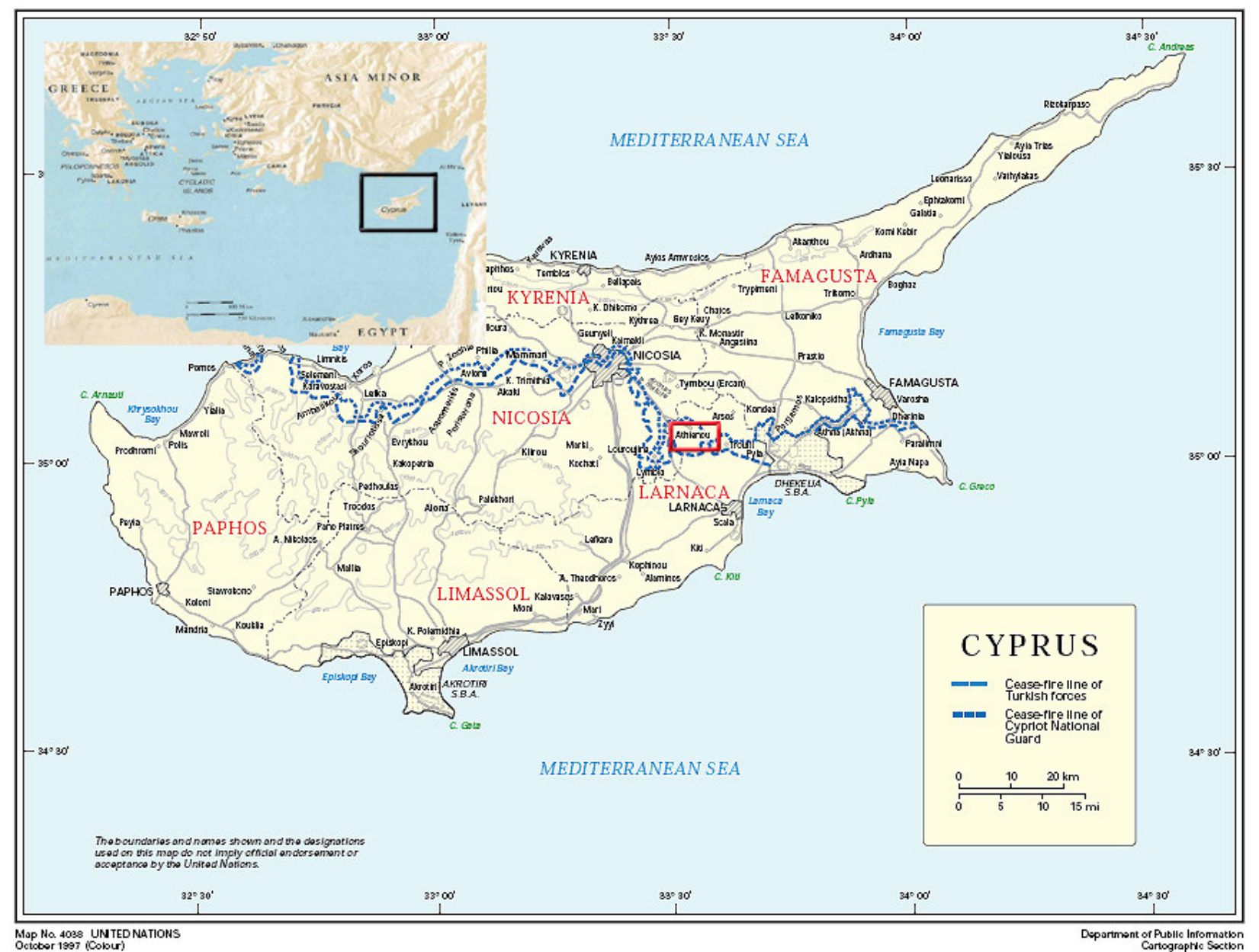

Figure 1. Map of Cyprus showing location of Athienou and the Green Line that separates the Greek and Turkish sectors. The inset shows the location of Cyprus in the eastern Mediterranean area.

\section{CYPRUS}

Since 1990, the Athienou Archaeological Project (AAP) has conducted excavation and survey to determine the cultural dynamics of the Malloura Valley in central Cyprus over a period of eight millennia (Figure 2). The specific problem that guides this research is the degree to which rural areas or backwaters were assimilated into regional and interregional economic, political, social, and religious networks of material and symbolic exchange (e.g., see Knapp 1988). While the Athienou region, and in fact Cyprus as a whole, can be viewed as marginal in the evolution of western civilization, the project area can, nonetheless, be seen as a laboratory for the study of culture change. It is vital to study such rural areas to balance the overemphasis on urban centers in most examinations of ancient and medieval Mediterranean culture.

The combined data from prior work and that of the AAP provide a picture of occupation in the vicinity of Athienou (Figure 3). Lithics from three sites on the hills that border the western edge of the Malloura Valley reveal similarities to the assemblages from Aceramic Neolithic (AN) (7000-5500 B.C.) sites, so we have tentatively dated the sites to that time period (Kardulias and Yerkes 1998). The survey revealed no evidence of Ceramic Neolithic (5500-3800 B.C.), Bronze Age (2400-1050 B.C.) or CyproGeometric (early Iron Age, 1050-750 B.C.) period occupations in the Malloura Valley (Figure 3). It 
appears that settlement during these periods was limited to adjacent areas north of the valley, such as the late Bronze Age site at Athienou Pamboulari tis Koukouninnas, a metal production facility. Pamboulari exhibits characteristics of a regional production center (Dothan and Ben-Tor 1983).

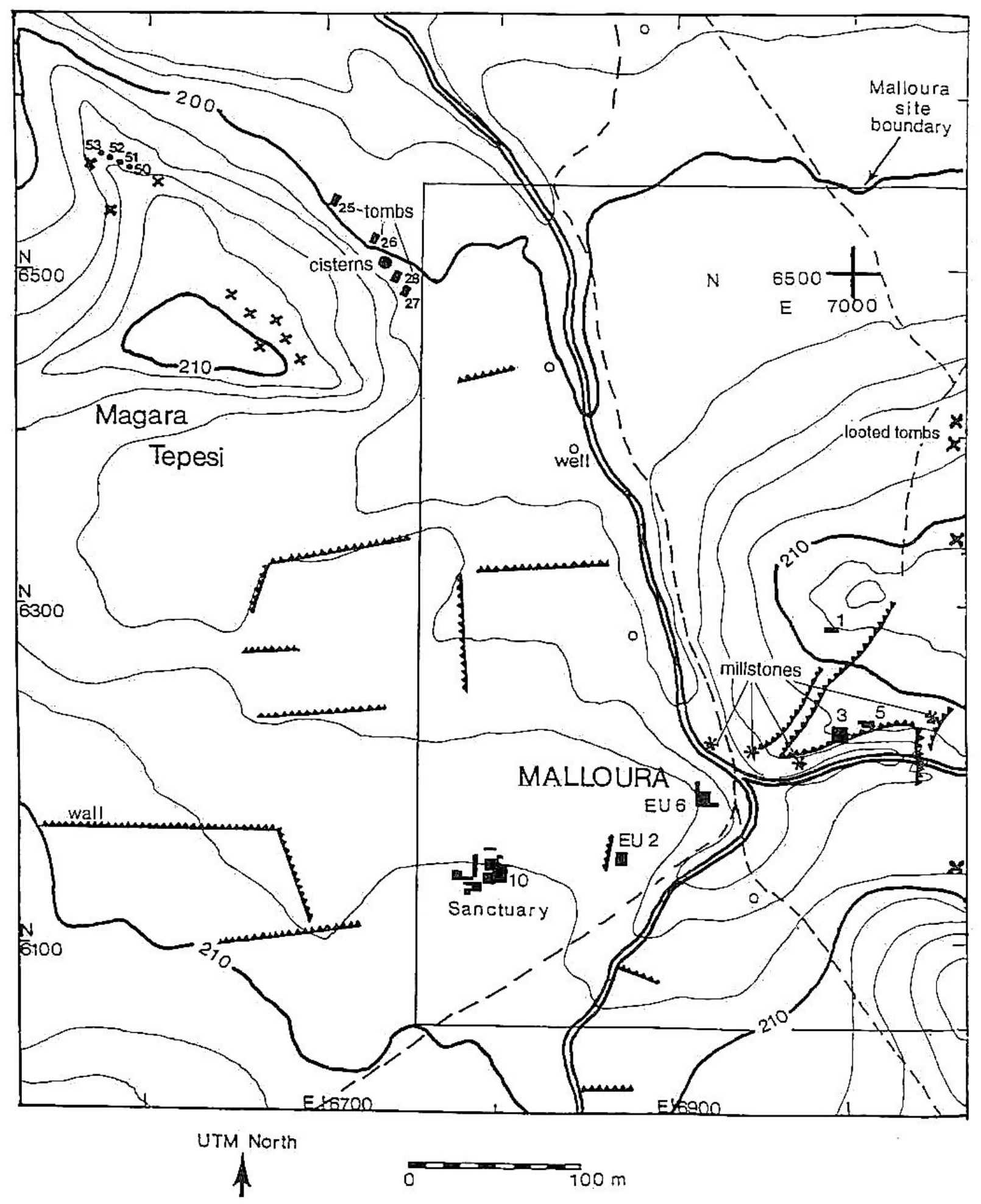

Figure 2. Contour map of region around ancient site of Athienou-Malloura. Locations of excavation units (EU), tombs, and the rural sanctuary are indicated. 
Mavrous NE
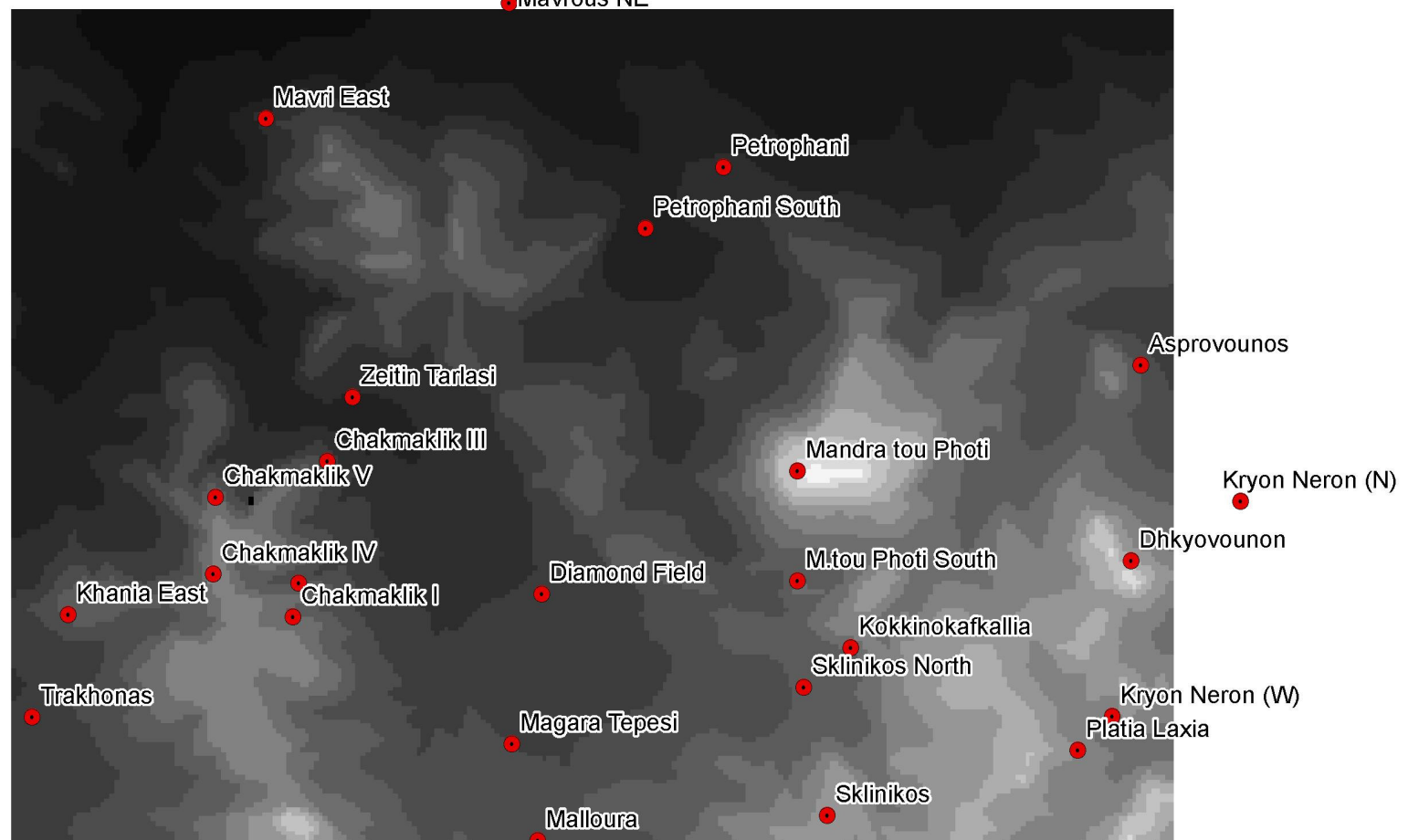

Khirin Kourats

.

Jinarotos East

Acropolis SE Mesovounos

Koutsopetrika East

\begin{tabular}{lrrrrr}
0 & 205 & 410 & 820 & 1,230 & 1,640 \\
\hline & & & & \\
\hline
\end{tabular}

Figure 3. Digital elevation model of AAP project area showing sites discovered by systematic survey. Lighter sections indicate higher elevation. 
The prosperity of the Late Bronze Age, the destruction during the era of the "sea peoples" (Drews 1993: 11-12), and the foundation of new cities on the coast (e.g., Salamis, Amathus and Kourion) during the early Iron Age, had very little impact on the more marginal areas of the island like the Malloura Valley. In the Archaic period, the focus of occupation in the region shifted to the area around the important Sanctuary to Aphrodite at Golgoi (Mbakalakis 1988). In this same period, the rural sanctuary at Athienou Malloura came into existence, and residents began to bury their dead in rock-cut chamber tombs in several locations near the new sanctuary. A large village developed at Malloura in the Roman period in the $1^{\text {st }}$ century A.D. This was the major site in the valley from the Roman through Early Byzantine (50-647 A.D.) periods; after a hiatus during the late $7^{\text {th }}$ through $12^{\text {th }}$ centuries (originally as a result of Arab raids on the island), the valley and its main village were reoccupied in the Frankish era (1191-1489) and continued into the Venetian (1489-1571) and Ottoman (1571-1878) periods (Table 1).

Table 1. Chronological Chart of Cypriote Prehistory and History

\begin{tabular}{ll}
\hline Neolithic & $10000-3800$ BC \\
Chalcolithic & $3900-2300$ BC \\
Bronze Age & $2300-1050$ BC \\
Geometric & $1050-750$ BC \\
Archaic & $750-475$ BC \\
Classical & $475-325$ BC \\
Hellenistic & $325-50$ BC \\
Roman & 50 BC - AD 395 \\
Early Byzantine & AD 395-647 \\
Arab-Byzantine Conflict & AD 647-965 \\
Late Byzantine & AD 965-1191 \\
Frankish & AD 1191-1489 \\
Venetian & AD 1489-1571 \\
Ottoman & AD 1571-1878 \\
Modern & AD 1878 $\rightarrow$ \\
\hline
\end{tabular}

In world-systems theory terms, the Malloura Valley in the prehistoric and early historic period served the role of extraction zone for neighboring regions. In this context, incorporation takes on a different meaning since we have no evidence of settlements, just the use of valley resources. The exploitation of local chert may well have been in the form of embedded procurement forays (Binford 1980) by inhabitants of sites such as Idalion Agridhi to the west. Embedded procurement involves the inclusion of several different tasks within a primary one, e.g., stopping at a stone quarry while out on a hunting expedition; the search for food may take one close to another resource, which is then visited as a second-level priority. In this case we may have an example of a regional system, or small-scale worldsystem (Chase-Dunn and Mann 1998), comprised of a series of egalitarian groups. In such groups, governed by consensus, the voice of individuals must be heard. The evidence from various AN sites, such as Khirokitia, Tenta, Kholetria Ortos, and Shillourokambos (Guilaine et al. 1995) suggests scattered pockets of habitation throughout the period.

Despite the fact that the AN culture of Cyprus clearly derived from the Asian mainland, from the outset the islanders seem to have developed their own distinct identity, with certain common features, but also a number of unique elements. Not only do the sites on Cyprus and the mainland seem to be independent, the AN people on Cyprus itself also seem to have lived in autonomous social units with only a veneer of common features to link them together. In a world-system in which shared information is the highest level of interaction, one would expect to find evidence for self-reliance, shared traits of a technological nature, and perhaps some common stylistic/cultural features. The nucleated settlements 
that existed in this period suggest small clusters of population who exploited the areas immediately around the villages, and went further afield for other necessary materials. The Malloura Valley seems to have served as one location where people from several settlements could come to extract workable stone. Kingsnorth (in Knapp and Given 1996: 346) suggests that blades and bladelets, which are found in some of the Sydney Cyprus Survey Project transects and may be AN in date, were locally produced from materials gathered throughout the region; in this region of the Troodos foothills, it seems that people in the AN utilized stone sources within a relatively small catchment area, although they did not inhabit the quarries proper. This is the same pattern we see in the Malloura Valley, where people mined Sites 9, 15, 21 and 28 (Chakmaklik I-IV in Figure 3) for chert that they then transported elsewhere for final reduction and use. What the Malloura Valley evidence may indicate is the spacing of AN settlements across the Cypriot landscape, that is, the early farming people placed their settlements on or adjacent to the most critical resources, primarily arable land and pasture for domesticated animals, but within reasonable distance of other necessary materials, such as flakable stone. The presence of non-local materials at a site indicate that Neolithic inhabitants knew how and where to obtain such resources (information network); we can trace the extent of this information by, for example, comparing the types of chert present at a site with the known sources of the stone. Since AN prestige goods are largely limited to ornaments made from certain types of stone found in several places on the island, the presence of various types of lithic materials at sites suggests an overlap between the information and prestige goods networks.

The pattern in which individual sites were strategically located to exploit both local and exotic materials continued into later prehistory. Such sites have evidence for both particular information and valued goods. While there are no Bronze Age sites in the Valley, Pamboulari tis Koukouninnas just north of Athienou was a significant metal production facility; the Archaic sanctuary of Golgoi also developed in this sector. These sites represent the nesting of information and prestige goods networks (Chase-Dunn and Hall 1997: 52-55) in the region and are clear indicators of a growing connection with both other areas of the island and the international community.

The best evidence for the early historic phases comes from a rural religious sanctuary at the site of Malloura (Site 1) in the center of the valley (Figure 2). In the first phase of the survey we conducted a systematic collection over the entire surface area of the site ( $26 \mathrm{ha}$ ) in order to identify activity loci by time period and to create a baseline of artifact types and quantities for the remainder of the valley. The survey has worked in direct conjunction with excavation at Site 1, clearly the location with the longest occupation in the valley. In the sanctuary in the sw corner of Site 1, extant peribolos walls reveal the enclosed area was ca. $400 \mathrm{sq} \mathrm{m}$. The major finds include large numbers of limestone statuary ranging in size from a few centimeters to over life-size; Cypro-Archaic and Cypro-Classical terracotta figurines of helmeted warriors, chariots, and animals; large amounts of decorated and plain pottery (mostly Archaic); limestone utensils (e.g., offering vessels, vessel lids); and a few bronze and iron artifacts. Several statuary pieces betray Egyptian, Near Eastern, and East Greek influences. A few examples of female figures were found, but the overwhelming majority of the statues represent male votaries and divinities such as Baal-Hammon, Herakles-Melqart, Apollo, and Pan (Toumazou et al. 1998; Figures 4 and 5).

At this point in the history of the Malloura Valley there is, thus, clear evidence of external influences. Some of the statuary betrays Phoenician influence, if not workmanship. There was a definite Phoenician presence (perhaps even colonies) at several coastal sites in this period, but there is much debate concerning the degree to which they penetrated the interior. What our data reveal is possible religious syncretism in which native Cypriots melded elements of foreign origin with their own version of the Greek pantheon; this process in some ways mirrors the blending of Christian elements with native religions in the Americas (Oakes 1969). Indeed, what we may be seeing here is the natives of the valley negotiating their peripheral status in the east Mediterranean world system, adapting outside elements to their own particular needs. In this sense, the level of incorporation still involves only the information and prestige goods networks (Chase-Dunn and Hall 1997). 

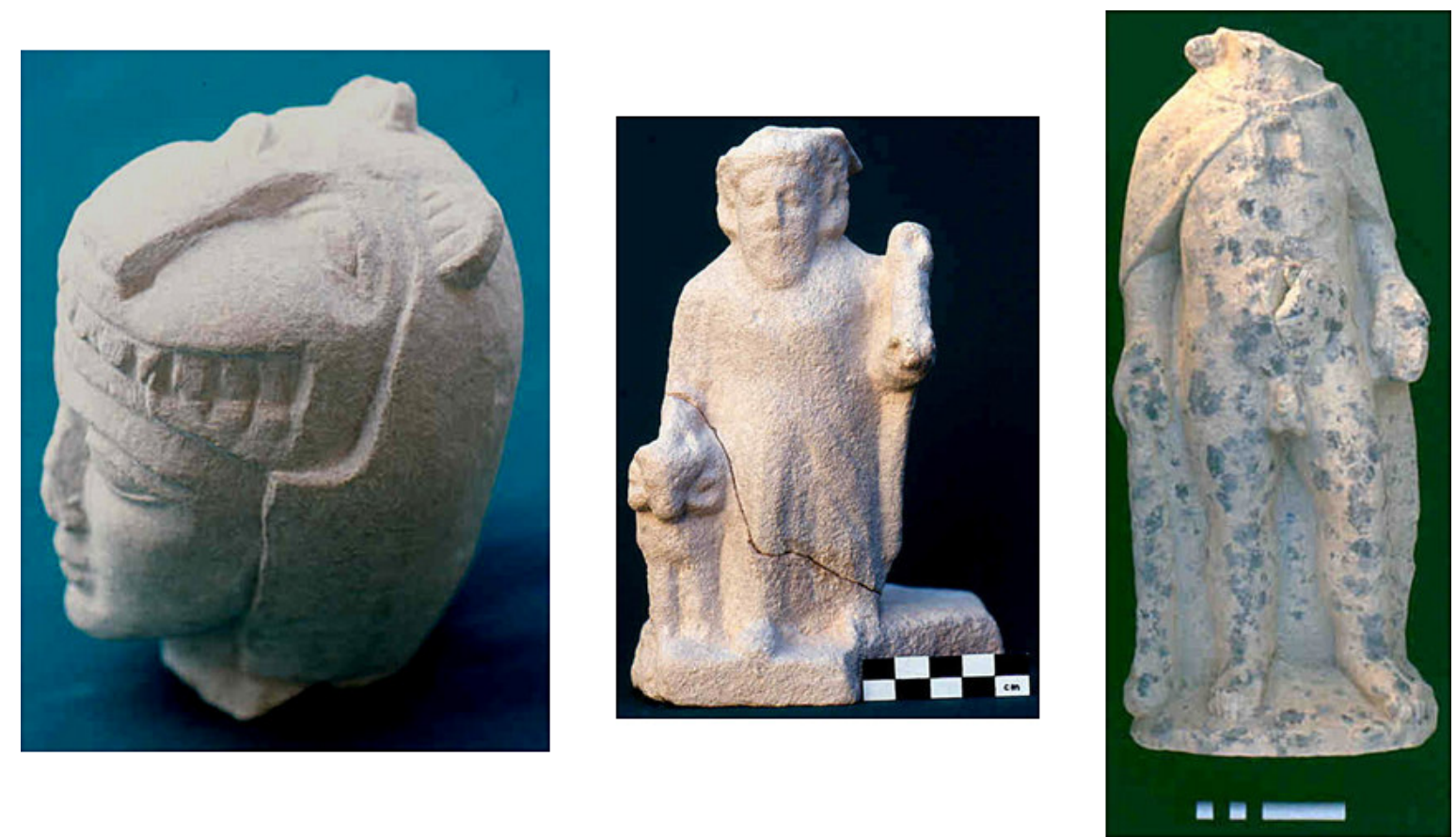

Figure 4. Limestone statues from the Malloura Sanctuary. Herakles (at left) wears characteristic skin of Nemean lion from his first labor. The Herakles and Pan (right) figures fit directly into the Greek pantheon, while the Zeus-Ammon (center) reflects Egyptian influence.

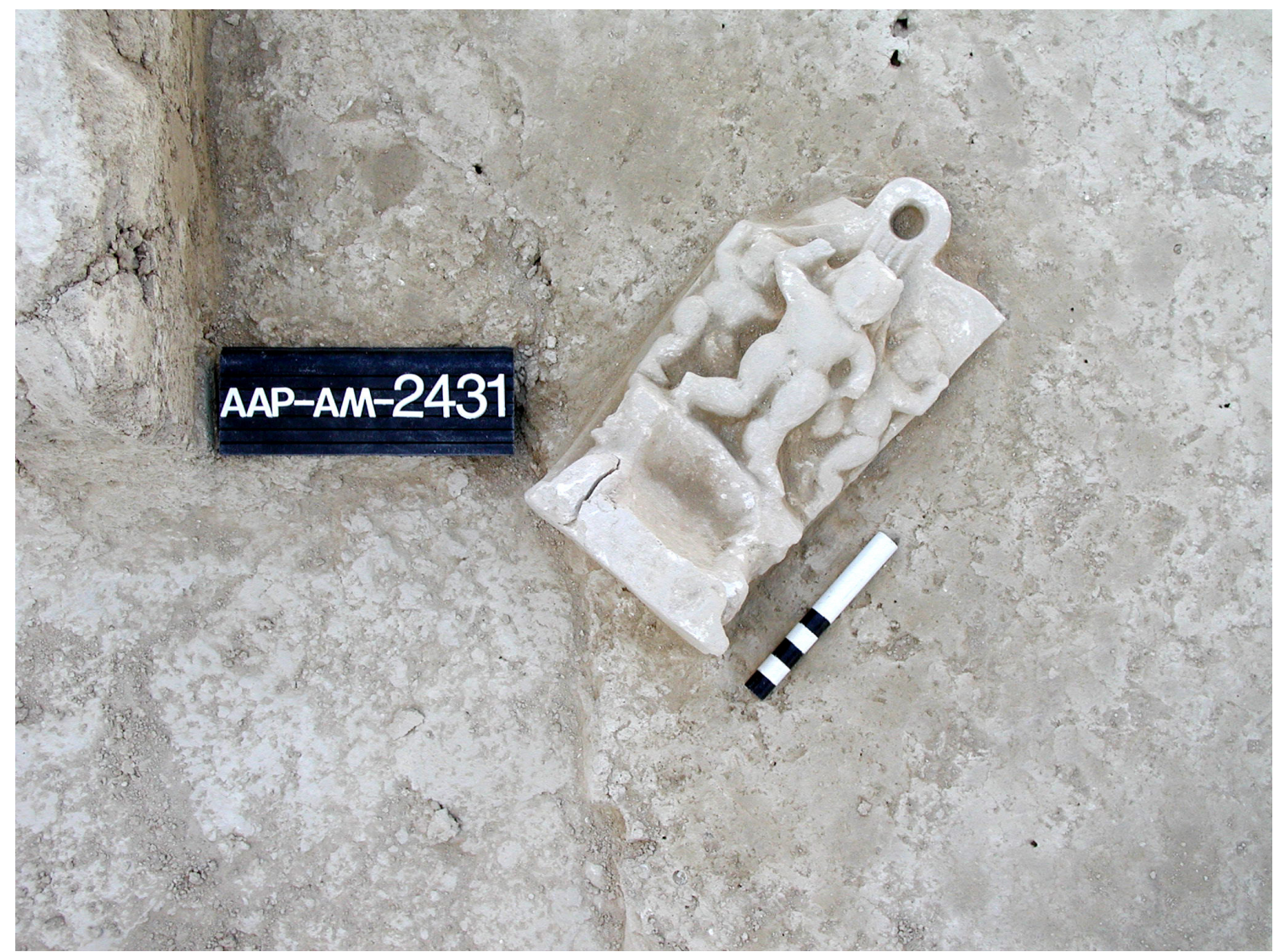

Figure 5. In situ limestone relief figure of Egyptian god Bes in the Malloura Sanctuary. 
This perspective is generally supported by burial evidence in the valley. Moderate scatters of Cypro-Archaic, Cypro-Classical, Hellenistic, and Roman material were found around the looted rock-cut tombs nw of the Malloura site at Magara Tepesi. Excavation and survey here revealed a cluster of four small looted chamber tombs on top of the hill (Tombs 50-53), and four large tombs (25-28) cut into the massive white chalk at the base of the hill. The typical construction plan was a stepped dromos leading down to a single chamber with three benches cut into the rock, a pattern that is common in many parts of Cyprus in the last half of the first millennium B.C. Excavation of Tomb 27 (the largest in the group) retrieved large numbers of artifacts that were overlooked by the looters, including prestige goods such as silver and bronze coins, scraps of metal vessels and nails, gold and silver finger rings and earrings, a gold jeweled necklace, local and imported lamps, and ceramic vessels dating to the Hellenistic/Early Roman periods (325 B.C./A.D. 150). The quantity and temporal range of the pottery recovered shows that these tombs seem to have been used for generations by extended families. Careful sieving of the fill from Tomb 27 also yielded skeletal material from no less than 105 individuals.

The burial and other survey material reveals the presence of an elite community with strong links to local and distant markets; the status of the Malloura region seems to have been that of a semiperiphery that encompassed bulk-goods and prestige-goods networks nested within large-scale political/military networks in Hellenistic and Roman times. While Chase-Dunn and Hall (1997:52-53) argue that prestige-goods networks exceed political/military networks in extent, and thus the latter are nested within the former, I suggest that the relationship between the two networks oscillates; large empires or super-states regulate the exchange of prestige goods to a much greater degree than small states, chiefdoms, tribes, and bands in which elite materials cannot be fully controlled by a central authority. When highly centralized states collapse, the access to prestige goods broadens.

World-systems theorists often present the semiperiphery as the location of major innovation and change (Chase-Dunn and Hall 1997:78-93). While scholars often think of rural areas such as the Malloura Valley as recipients of influences from cosmopolitan centers, it is important to consider the way that such patterns were transformed after they reached the hinterlands (cf. Schortman and Urban 1994, 1999). The prestige goods buried in the tombs probably reflect the direct emulation of elite lifestyles from urban centers by the local Malloura lords. The mixture of religious symbols in the sanctuary, however, reflects syncretism in which foreign deities were made palatable to residents of this particular region. The survey revealed the lack of a substantial settlement to correspond with the tombs and the sanctuary. We suspect that the limited evidence for habitation in the valley indicates extensive use of the land for agricultural production, as is still the case today. Chase-Dunn and Hall (1997:91) call this pattern of land use a "commodified mode of accumulation" in which agricultural products were grown and sold. Their assertion that this activity took place in "capitalist city-states in the semipheripheral interstices of empires dominated by the tributary mode of accumulation" (Chase-Dunn and Hall 1997:90) provides a useful model for Cyprus.

The pattern of nucleated settlement in the valley continued throughout most of the first millennium A.D. Several excavation units (EUs) at the Malloura site contain the remains of structures associated with the establishment of a substantial rural settlement at Malloura during the Early Roman period that continued through the Early Byzantine era (A.D. 395-647). In EU 3 in the se quadrant of the site, there is an Early Byzantine domestic structure that was burned in the mid-seventh century, early in the period of Arab/Byzantine (A.D. 647-965) conflict. Surface materials also suggest that the earlier settlement at Malloura was abandoned at this time. Just to the east, another structure of similar construction and orientation was discovered that dates from the Roman through Early Byzantine periods. The pottery associated with the building included imported African Red Slip, Phocean Red Slip, and Pompeian Red wares; the pottery here also indicates that the settlement was abandoned in the seventh century. Despite its location $15 \mathrm{~km}$ inland and behind the Vouyes ridges that overlook the Larnaca coast, Malloura may have fallen victim to the first Arab raids on Cyprus. This circumstance suggests that these raids were not confined to the littoral regions. 
Materials dating to the Roman/Early Byzantine occupation of the Malloura Valley were not as common as Late Byzantine/Venetian artifacts in the survey tracts. Moderate scatters of Roman and Byzantine materials were present in the fields around Petrophani, at Site 16 in the northern portion of the survey area, and at Site 30 along the Nicosia-Larnaca road on the western edge of the valley, but it does not appear that there were substantial Late Roman/Early Byzantine settlements at these sites.

Our data on the Roman and Early Byzantine occupation of the valley directly reflect the development of a single political/military network (Chase-Dunn and Hall 1997:61). In fact, we can go back to the late Archaic period when the Persians made Cyprus into a province or satrapy, for an earlier example seen elsewhere in Cyprus. Particularly in such instances of conquest, it seems that political incorporation preceded economic incorporation. While there were certainly commercial contacts between Cyprus and Persia prior to the conquest, the level of integration increased significantly when the island became part of the Achaemenid empire. I would argue for a similar process in later times. From the late first century B.C. to the mid-seventh century A.D., Cyprus was a province of the Roman Empire and its successor, the Byzantine state. This thorough incorporation (by which I mean political and economic union of a periphery into the core, typically entailing colonial administration) involved not only a position in the imperial political structure, but also a role in the economic oikoumene in which economic exchange occurred regularly and largely peacefully across much of the Mediterranean basin as part of the Pax Romana. Even rural backwaters like Malloura enjoyed access to the products of this farflung economic system. The presence of the various imported ceramic wares is testimony to this fact. Bulk goods of various types, probably including grains and animal products from Malloura, may have been key items exchanged among the Cypriot towns and regions, and sent abroad as well in return for the foreign finished goods. In addition, an important component of the information network that functioned to provide some social glue to the economic transactions was Christianity, which gained the virtual status of a state religion in the fourth century A.D. with its adoption by Constantine; of course, religion can be a divisive factor, as we have seen in Northern Ireland, Bosnia, and Iraq in modern times, but under the right conditions, it smooths relations by offering an element of common identity. Finally, the Arab raids that seem to have led to the abandonment of the Malloura Valley for a period of several centuries mark Cyprus as what Allen (1996; see also Cline 2000) calls a "contested periphery", i.e., a region in the interstices between major states over which the latter fight for control. In fact, Cyprus can be defined as a contested periphery from antiquity to the present day because of its strategic location at the crossroads of Europe, Asia, and Africa.

The Frankish and Venetian periods represented in excavation and survey material from Malloura indicate a strong degree of incorporation into the respective world-systems of the western powers. For Cyprus as a whole, the historical documents demonstrate how the western knights thoroughly dominated the indigenous rulers and then pursued certain economic interests by turning many areas to the production of sugar cane. In this period, as in several previous ones, political incorporation preceded and facilitated economic incorporation. Under the Venetians, Cyprus became an entrepôt, a major base for their commercial empire. These efforts filtered into the hinterland at Malloura in the form of a resurgent village. Clearly, though, the ancient pattern of nucleated settlement remained in place. Once again, Malloura became one local node in an international system that produced substantial wealth in the village. The amount of grain processing represented by a number of large millstones suggests production at a level capable of providing a surplus that may have subsidized the purchase of fine ceramics for domestic and funerary uses. Whether we are dealing with direct Venetian control of the Malloura Valley, however, is not clear from the evidence at hand.

We have identified as lookout posts four sites from the Roman and later periods; we believe these reflect the continuing status of Cyprus and the Malloura Valley as a contested periphery. In part, these sites may reflect the clash of imperial giants (e.g., Venetians vs. Ottomans), and probably also the concern with raids by pirates or corsairs at various times (Figure 6). While the valley probably never offered the 
kind of concentrated wealth found in urban centers, its location on the route between the port of Larnaka and the major city of Nicosia would have placed its residents and their agricultural produce at risk from marauders.

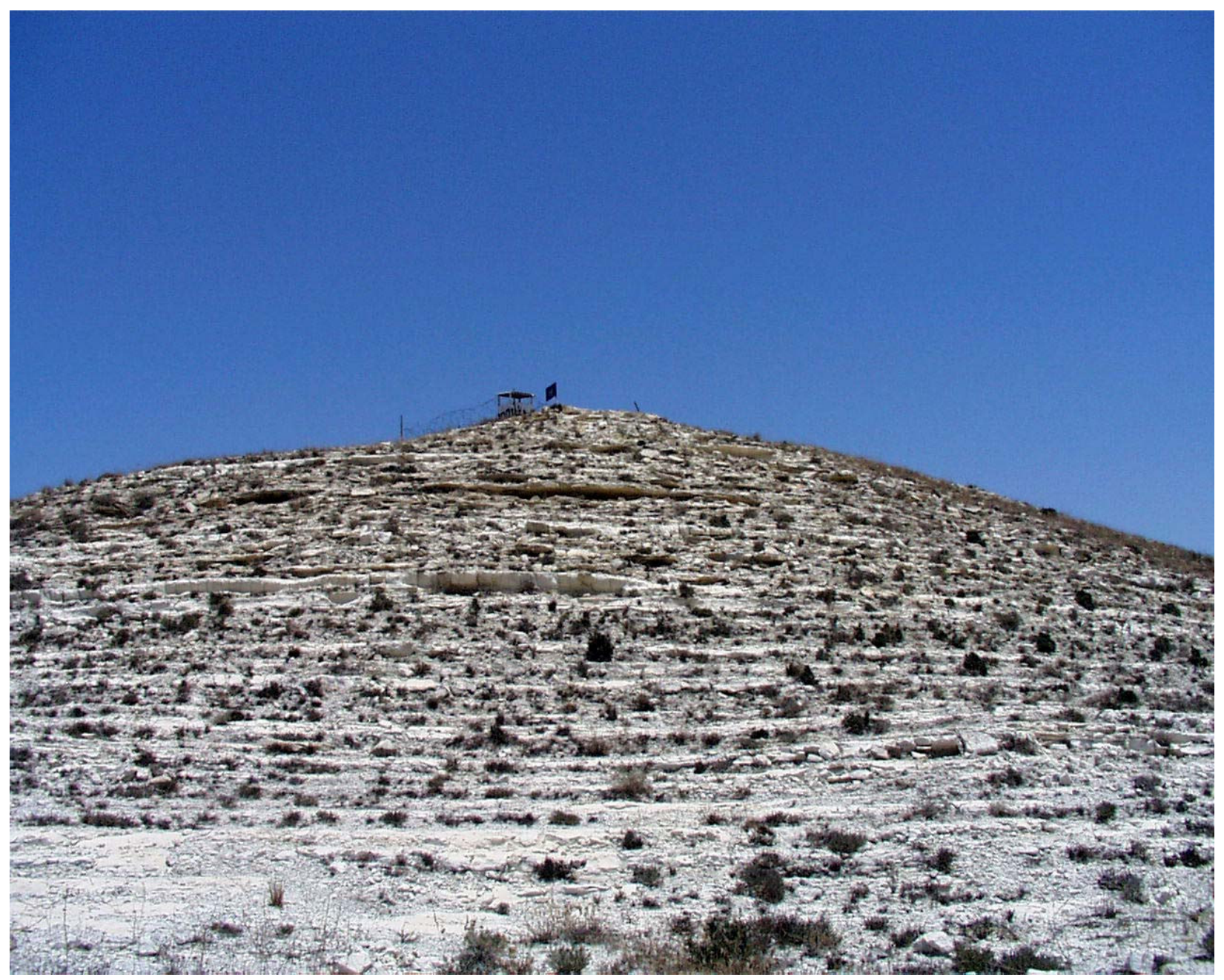

Figure 6. View of Site 14 on top of hill in northeastern part of AAP project area. A U.N. sentry post with barbed wire sits on top of the site. Both ancient and modern people have used the location as a vantage point because it provides a panoramic view of the valley and of the Mesaoria plain to the north. Facing eastnortheast.

The decline of Malloura (Site 1) and the development of the village of Petrophani (Yerkes 2000) at the northern end of the valley were probably linked events in the past 125 years. The scatter of isolated farmsteads and lithic workshops from the modern period represent local management of resources and production of certain agricultural implements, such as threshing sledges (Kardulias and Yerkes 1996), within the context of a truly global world-system. Cypriot products of all types, including olives, oil, carobs, and today milk and cheese, moved from small villages to regional centers, and then into overseas markets via the British imperial system. The town of Athienou grew into a local market center that serviced both Greek and Turkish hamlets, such as Petrophani, and we suspect Malloura lost its residents to the emerging town. The culmination of many of these processes came in the 1970s when Cyprus, ever the contested periphery, was invaded by Turkish forces. The people of Athienou who lost 
access to their farmland north of the town turned to the former Turkish-held land in the Malloura Valley and converted large tracts of land to barley production (Figure 7). The grain feeds large herds of milk cattle that have made the region one of the most productive dairy areas in that part of the Mediterranean. The people now market milk and cheese throughout Cyprus and the Levant. Despite the fractious political situation, the bulk-goods network has become a key component of the economic system. Here is yet another example of the the people of the Athienou/Malloura region taking an active part in defining their destiny.

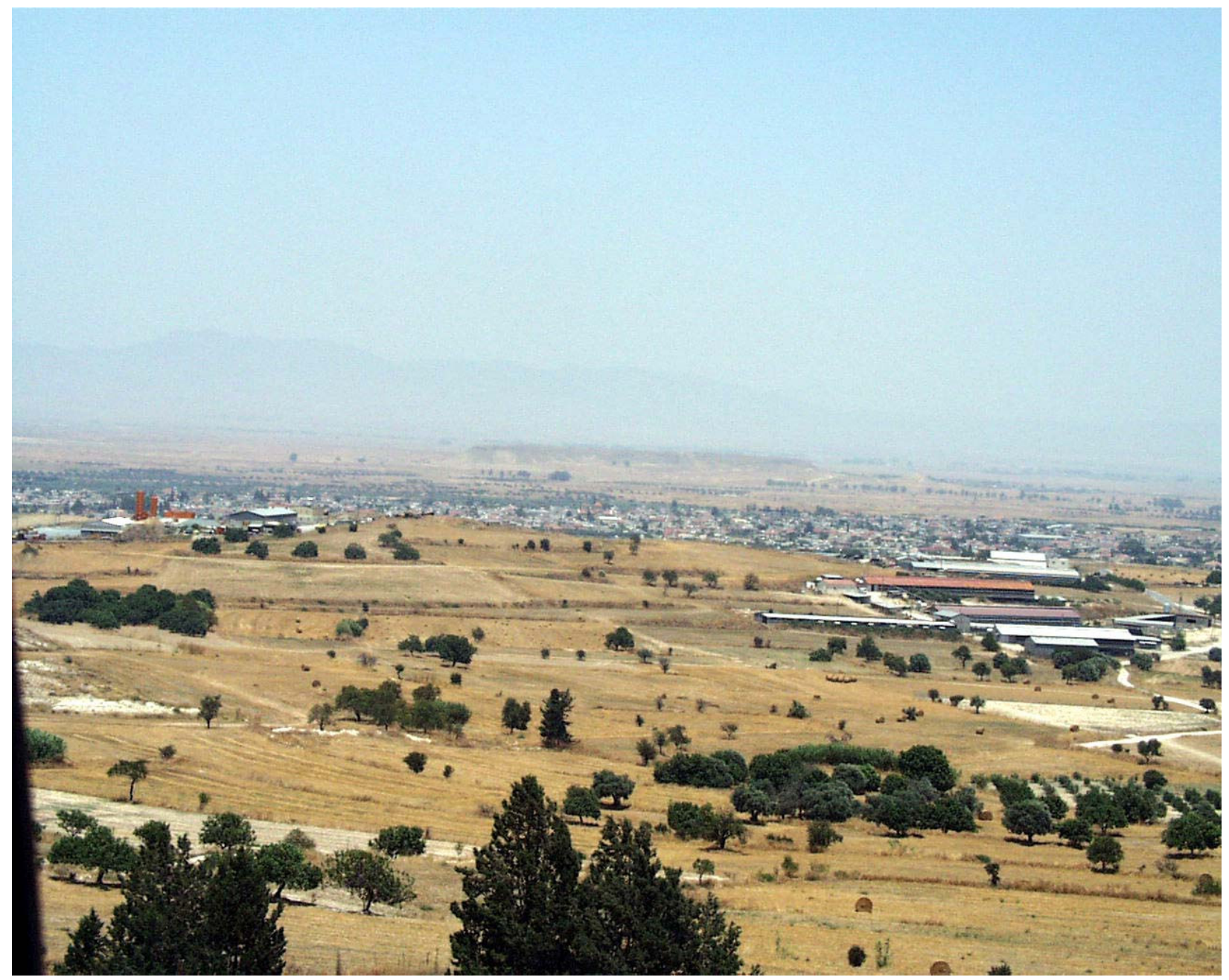

Figure 7. View of the north end of the Malloura Valley. Barley fields reach to the edges of Athienou in midground. To the right are pens for cattle; the dairy industry in the area developed after the Turkish invasion of 1974 when the people of Athienou lost access to their farmland shown in the background beyond the town. In the distance is the Kyrenia Range. Facing north.

\section{THE NORTH AMERICAN FUR TRADE}

This section examines the economic and social impact of the fur trade on North American Indian cultures. The Indian role in the fur trade can be described as a craft specialization, within the context of the emerging modern world-system. To explain the emergence of specialized production of furs among Native Americans, I subscribe to a decision model based on rational choice (Barth 1959; Homans 1958) 
that considers both real and perceived needs. For North American Indians, these needs included the acquisition of European products and the development of alliances with Europeans to serve native concerns. While the specific ends that Indians and Europeans desired were different, the basic process was the same. Native peoples wanted objects both for their practical uses and relevance as status markers, while Europeans were ultimately interested in profit. Trigger (1991) also suggests that native peoples acted to benefit themselves, and he further notes that those interests shifted over time; he argues that Indians first saw European goods as prestige items, then as utilitarian objects, accompanied by a shift in their views of foreigners from exalted to inferior status.

Negotiation and maneuvering by both sides characterized the fur trade from the outset. The Indian role, influenced as it was by the desire to obtain Western goods, required modifications in various native practices to permit full exploitation of the network. Indians altered production strategies to suit their own perceived interests. They engaged in procurement, processing, and use/consumption activities that were embedded in the procurement sphere of the European market. Indian involvement in the fur trade was a microcosm of the larger world-system network (Figure 8). It is important to note that this process occurred prior to thorough incorporation, i.e., before Europeans established formal political dominion over the native groups. In this instance, trade led the process of incorporation. The logistics of Atlantic travel and the nascent character of political consolidation in sixteenth century European states prohibited the French and others from establishing political authority over indigenous people for over a century. The appeal of manufactured goods, however, drew Indians into economic relationships with the Europeans. While the indigenous people served their own ends, their role in the European system was primarily extractive. ${ }^{1}$

Structural changes occurred in native societies to facilitate such shifts in economic emphasis and involved the development of craft specialization. Native Americans exhibited an entrepreneurial spirit in manipulating the system to their advantage and, in doing so, adopted specialized economic behavior. By entrepreneurial in this context I mean that indigenous people weighed advantages against risks and took the path that seemed most likely to accomplish their goals; in this respect they mirrored their European counterparts, even though the specific ends were different (see Brandão 1997). Native American societies exhibited remarkable flexibility in adopting, absorbing, and manipulating European goods and practices within an Indian context. Social practices, kinship structure, and other elements felt the impact of the fur trade, but the agenda for change was an Indian one, despite the inability of native groups to foresee the ultimately catastrophic effects of this involvement.

It is within this general framework that the production of furs for the European market by Indians is examined below. The primary contention is that the acquisition of furs by natives was transformed as a result of contact with whites from being one aspect of the economy to being its main focus. In this process, various Indian groups were not just passive recipients of European influence, but rather exercised the ability to select from amongst various options. Especially among the hunting and gathering societies of eastern and central Canada and the northern United States, the choice was most often to invest heavily in the hunting and trapping of fur-bearing animals, especially beaver. A number of horticultural groups also opted to pursue this route. This activity makes sense as a specialization only in relation to the European market which generated the demand for furs. In this way, the Indians became

\footnotetext{
${ }^{1}$ The fur trade had several other components that mark it as a prime example of the interconnected nature of the capitalist world system. Once the beaver coats were taken to France, Dutch ships transported them to northern Russia to remove the inner fur, that was then shipped to Amsterdam. Dutch merchants sold the beaver fur to manufacturers in England and France who transformed it into felt for hat production. Huguenot artisans who migrated from France to England after 1685 helped shift the center of hat production to the British Isles. Discarded hats were recycled by reducing the size and selling them to less affluent customers. Some old hats were reinforced with gum for the Spanish market. The Portuguese bought these recycled hats after they were discarded in Spain and Brazil, and then sold them in Africa (Kehoe 1992:253-254).
} 
crucial members of an international economic system; they were, in fact, the productive source and thus an indispensable element in the system (Saum 1965).

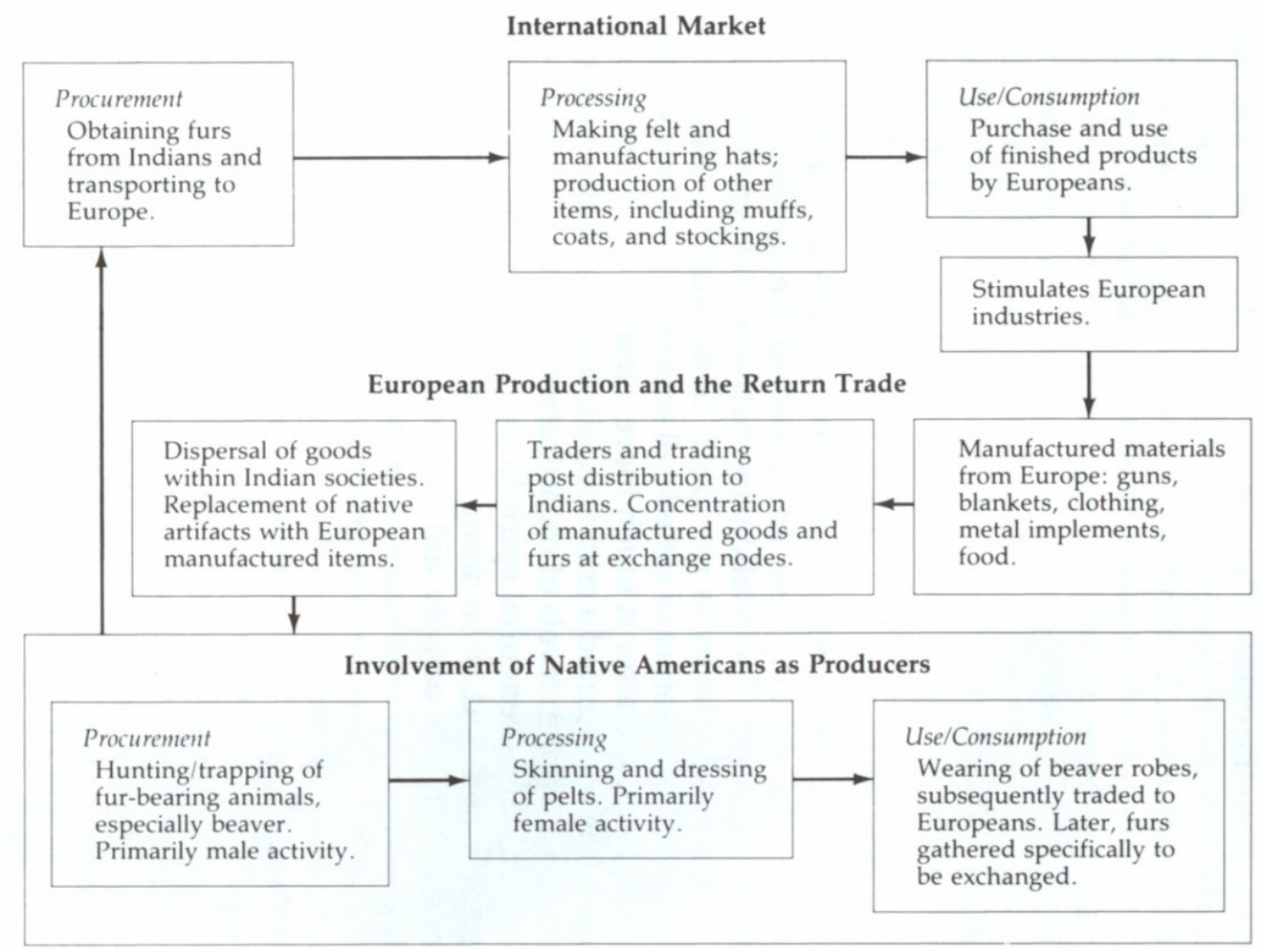

Figure 8. Diagram of Indian role in fur trade.

To better comprehend why the Indian role in fur production is deemed a specialization, it must be viewed on two levels. If viewed from the wider perspective of the international economic scene, Indians fulfilled the role of procurement specialists. They acquired the raw materials that were subsequently transformed into finished commodities in Europe, then distributed and consumed on that continent. In this scheme, the Indian was one $\operatorname{cog}$ in a highly diversified economic mechanism, i.e., one node in a commodity chain. On another plane, this procurement sphere can be seen as encompassing acquisition, processing, and consumption activities of its own, quite apart from the final disposition of furs in Europe. Natives captured the fur-bearing animals, dressed the pelts, and utilized the skins for immediate utilitarian or trade purposes. All of these activities were already part of Indian life well before the arrival of Europeans. In addition, Native Americans had developed complex trade networks well over a millennium before contact. For example, the Hopewell Interaction Sphere involved long distance trade in which prehistoric people of Ohio received obsidian from Wyoming, copper and some silver from the upper Great Lakes, mica from the Carolinas, pipestone and galena from Illinois, marine shells from the Gulf coast, and grizzly bear canines from the Rocky Mountains (Griffin 1967; Milner 2004:82-83), establishing an extensive Native American world system. More localized systems (small world-systems; see Chase-Dunn and Mann 1998) involved trade of various materials (including flint and probably some foodstuffs such as corn in the Midwest) within regions. However, this series of activities did not take on the stature of specialization until the trade with Europeans began. European demand stimulated the harvesting of furs at an unprecedented rate and diverted attention from traditional subsistence activities. 
This trend gained momentum during the entire history of the fur trade and fostered significant modifications in native societies.

\section{Fur as a Resource and its Exploitation}

Animal furs were the subject of Indian exploitation before Europeans arrived in North America, but the advent of the latter spurred the production of pelts to an unprecedented degree. This trade had begun in the early sixteenth century with French and Basque fishermen exchanging metal artifacts for the furs (Eccles 1969; Turgeon 1998). Eventually, the skins of a variety of animals (bears, moose, deer, marten, fox, various felines, and later, buffalo) became involved in this traffic, but the most important by far for over 200 years was the beaver (Figure 9). This animal was known to possess an exceptionally fine fur, but the European variety was practically extinct in western countries by the 1500s, with only limited supplies available from Russia and Scandinavia (Eccles 1969). The fur had two layers: (1) An outer layer of rather stiff guard hairs, each about two inches long and hollow to provide insulation and prevent the fur from becoming waterlogged; this part is coarse and shiny and gives the animal its color. (2) A fine, thick, downy undercoat, with individual hairs one inch long; these hairs have tiny barbs that make the fur cling tightly together when it is matted, as in the production of felt for hats (de Charlevoix 1761). It was the latter feature that made beaver fur the ideal form for hat manufacture and accounts for its immense popularity.

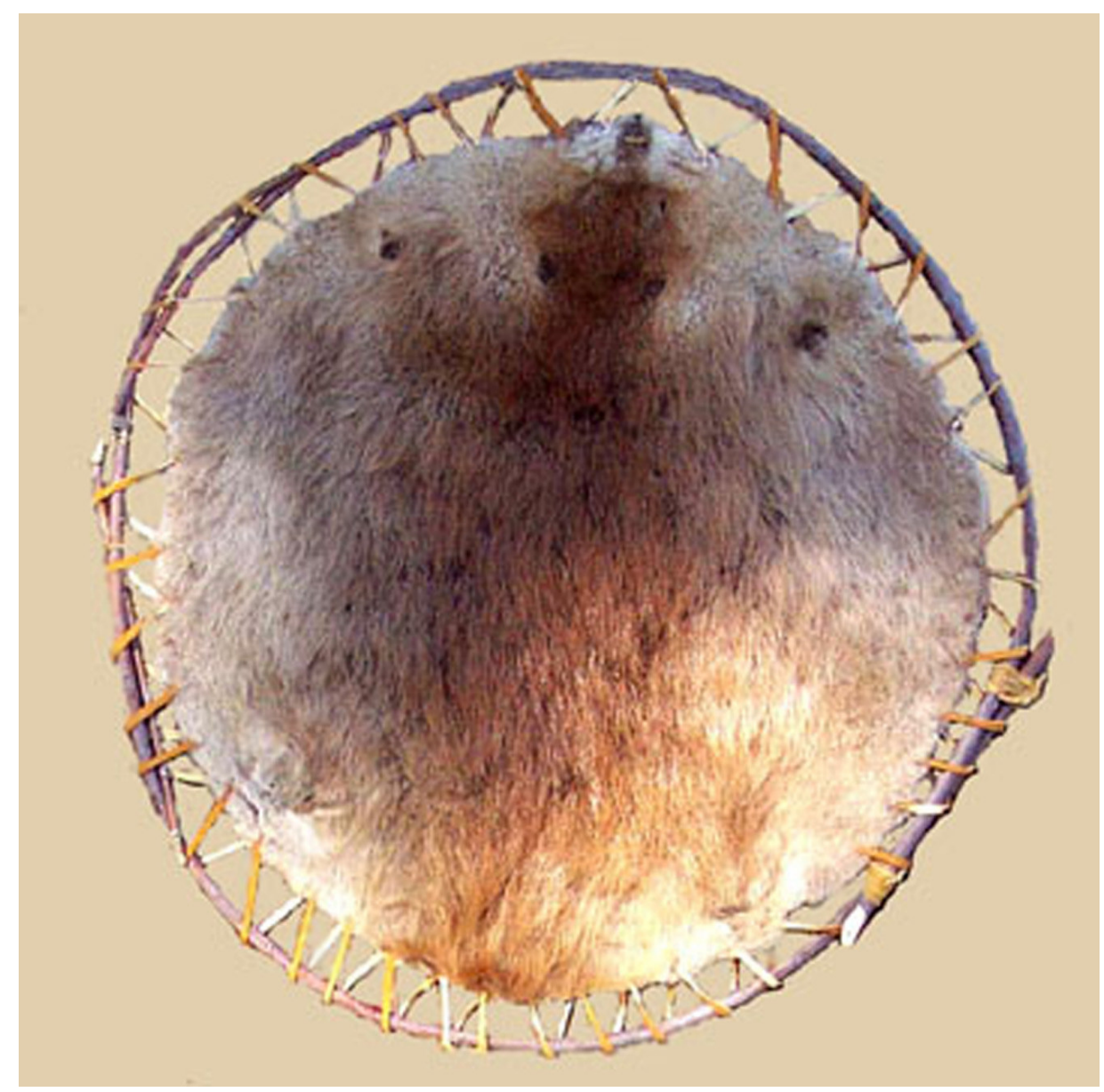

Figure 9. Prime beaver pelt. Photograph courtesy of Ned Eddins. 
From the European perspective, American furs, in particular that of the beaver, possessed several virtues: (1) They represented a commodity in short supply in Europe. (2) Because of their light weight, furs offered high value relative to bulk, could be readily packed and transported, and as a result, were highly profitable; early in the trade, a manufactured item worth one livre could be exchanged for a beaver robe that sold for 200 livres in France. (3) Indians performed most of the work, including delivery of prepared furs to European settlements; an economic partnership developed between the two parties involved in such transactions (Eccles 1969; Innis 1956).

\section{Material Cycle}

This series of events involved the procurement, processing, and use of furs. Each of these areas is treated separately, first in terms of what the aboriginal practice was, and then in light of alterations due to European contact.

The procurement aspect of this cycle refers to the hunting of fur-bearing animals. This activity generally occurred from mid-autumn to early spring, a time when animal furs were in prime condition. Some scholars (Eccles 1969:19, 1983:351; Innis 1956:15, 35; Richter 1983:539; Trigger 1985:173, 305, 310) have suggested that quality of furs increased with latitude due to colder temperatures (see Starna and Brandão 2004:730 for an opposing view). As the principle source of high-grade fur, the beaver was one object of Indian hunting in the pre-contact period, although not to the same extent as during the historic era.

In a general economic sense, this hunting phase can be considered equivalent to the extraction of a raw resource. Prehistorically and to a degree after contact, fur-bearing animals such as the beaver also served as important parts of the native diet (JR, 26:129; Trigger 1969; Murphy and Steward 1968; Francis and Morantz 1983), but when Indians shifted to full involvement in the fur trade, these animals became more than just a food item. Fur became the medium of exchange by which Indians received the valued European products (Kroeber 1939). The Jesuit le Jeune quoted an Indian who put the issue in such a light: "The Beaver does everything perfectly well, it makes kettles, hatchets, swords, knives, bread; and, in short, it makes everything" $(J R, 6: 297)$. This statement demonstrates the native realization that a concentration on beaver hunting could provide substantial economic rewards; in this sense, the emphasis on fur hunting became a specialized activity. Individuals known to be superior hunters of particular animals were called on to exercise their particular talents. This extractive part of the process was almost exclusively a male occupation. On rare occasions, netting of beaver could become a family affair (Craik 1975). By the nineteenth century, trapping was entirely male work. Men would spend the entire winter alone, or only in the company of other hunters, while tending the trap lines (Robinson 1879).

The second phase of the material cycle involved preparation of the fur. This was largely the duty of Indian women (Axtell 1980). To make the skin pliable, the flesh side was often smeared with a concoction of decomposed animal brains and liver, set aside for several hours, and then vigorously rubbed between the hands. This latter treatment was a common means of tanning various kinds of hides throughout North America (Peale 1872; Shufeldt 1889; Innis 1956). Calcareous soils, bone dust, or flour served as absorbing agents to remove this paste and to eliminate any excess moisture and remaining fat (Mason 1891).

Workers cut the prepared pelts into rectangular shapes and sewed between five and eight of these pieces together with moose sinew to make a robe. Natives wore this garment with the fur next to the body during the cold months and fur side out at other times. After extensive wearing for fifteen to eighteen months, the guard hairs, whose deep roots had been loosened by the scraping, dropped out, leaving only the downy fur or cotanne. In addition, the skin and fur became well-greased through contact with the body oil of the wearer, while the smoky interior of the Indian hut acted to cure the pelt. Because of this conditioning and the lack of guard hairs, such fur robes were ideal for the felting process used by European hat makers (Innis 1956). The first European traders simply bartered for the old robes the 
Indians had worn for some time, and for their part, the natives were more than willing to exchange an old garment for precious metal artifacts (de Charlevoix 1761).

As the fur trade developed, Indians increasingly focused on trapping in an effort to meet European demand for fur and, thus, obtain the valued manufactured commodities in return. Since not all of the furs could be treated in the elaborate manner of the robes, a system of grades developed, which, though framed in terms of European standards, Indians clearly understood. Castor gras d'hiver was the top rank fur that had undergone the whole treatment and so was devoid of guard hairs and was wellgreased and supple. Castor sec or parchment beaver was prepared by drying, and still had guard hairs because it was not worn. Demi-gras d'hiver referred to robes that the natives had just begun to wear, so the skin had not turned completely yellow. Castor gras d'ete were robes made of pelts that had less fur and thicker skins because these had been taken in summer. Castor veule robes had been scraped thin and treated, but not worn. Castor sec d'hiver or bardeau were skins taken in winter but not made into robes due to holes and imperfections; these were poorly prepared and rather coarse. Castor sec d'ete had been trapped in summer and was not made into garments. Finally, mitaines and rognures were small pieces used for sleeves and mittens in native apparel (Innis 1956:64).

Indians attempted to regulate the market by providing more of the lesser grades of furs as they intensified their concentration on trapping as a major economic pursuit (Danzinger 1978). Since European hatters needed a 3:1 ratio of castor gras d'hiver to castor sec, a huge surplus of the latter developed since it was much more expedient for the Indians to produce this type. This imbalance is reflected in the records of Ft. Frontenac; in 1722, 4,435 pounds of dry beaver (sec) was taken in compared to only 168 pounds of fat beaver (gras) (Preston and Lamontagne 1958). The stockpiles had reached such levels by 1700 that prices dropped, a factor certain French merchants tried to counteract by burning some of their stock (Vandiveer 1929). It is important to note that the number of furs in the market in any particular year did vary by region, as native groups gained or lost access to trapping areas. Nonetheless, this sequence of events indicates that Indians attempted to regulate production levels of fur in terms of their own economic interests. By the mid-seventeenth century the vast majority of the beaver and other fur being trapped by Indians was being funneled into the trade with whites.

\section{Native Americans as Traders}

The consumption aspect of the material cycle for the Indians involved the exchange of the processed furs for European goods. Native groups were by no means strangers to trading activity. Archaeological evidence indicates long distance indirect trade between Iroquoian (including the Huron) and Algonkian groups throughout eastern Canada and the northeastern United States was well developed prior to the arrival of Europeans (Wintemberg 1942; Wright 1972). Similar conditions existed in the northern Plains, reached by French traders in the eighteenth century (Ewers 1972). With such a system in place, what was needed to spur the development of intensive fur-gathering by native Americans was a large market and desirable exchange goods, both of which Europeans provided (Lawson 1972). The existing trade networks could readily tap a vast hinterland in which the natives turned to fur production on a large scale once they realized the advantages of trade goods. As a result of this native exchange system, many Indian groups acquired European products well before any direct contact with whites. The Huron, who were at the center of an extensive exchange system with connections in all directions, received their first European goods from their Algonkian trading partners prior to 1603, before Champlain's first visit to the region (Heidenreich 1971). The Chippewa of Lake Superior were already familiar with European products when the Jesuits made initial contact with them in 1641 (Danziger 1978). From the outset, the Indian's role in the fur trade was instrumental in the success of the system. Not only did the natives trap the animals and prepare the furs, but they also transported the pelts to collection points, such as the trading posts.

Native involvement in the trade took two forms. At the most rudimentary level, the various Indian groups could present their furs directly to the European traders. This was the situation when 
Indians initially encountered Europeans in the St. Lawrence region and in the coastal areas of the Maritime Provinces. The cod fishermen who came ashore to dry their catch bartered for the furs that the Montagnais, Micmac, and other hunting groups had collected themselves. So accustomed were the Indians to this trade by 1534 that when Jacques Cartier sailed into the St. Lawrence in that year, the Micmac enticed the French to trade by waving furs at the explorers (Trigger 1979). As Europeans penetrated the interior, they met still more groups who provided furs (Innis 1956; Marquette 1966; Norton 1974; Trigger 1976). The Europeans' need to maintain a large volume of business to cover their high transportation costs motivated this inland movement (Innis 1956:110). The seemingly insatiable European demand for furs led these and other Indian groups to concentrate on the hunting of fur-bearing animals to a much greater degree than had ever been the case prior to contact. As a result, traditional hunting grounds were quickly trapped out, and Europeans moved further afield in search of new Indian sources (Ray and Freedman 1978).

The second native form of involvement was an outgrowth of the declining population of furbearing animals in certain areas, combined with the desire of the Indians in such areas to continue the flow of trade goods. For a few groups in the proper geographical position, the major solution to the problem was to continue supplying the Europeans with furs by acting as middlemen. In this capacity Indians exploited the already existing trade networks. Such transactions concentrated on the acquisition of furs by the middlemen who in turn passed on some of their European materials to their native trading partners. Since the best quality furs were found in the cold regions north of the St. Lawrence and the Great Lakes, those groups that had regular contact with the northern hunters were in an enviable position.

In the first half of the seventeenth century, the Huron were the dominant middlemen in the French fur trade. Having rapidly exhausted the beaver supply in their home territory, the Huron used their considerable skills as traders to maintain the flow of manufactured products. They exchanged corn, tobacco, nets, and European goods for furs with northern groups such as the Nipissing (Trigger 1976). The Huron transported furs in large canoe convoys to French settlements on the St. Lawrence River. The French received 10,000 pelts annually, comprising anywhere from one-third to one-half of the total, in this manner from the Huron (JR, 60:211; Trigger 1976). When these people succumbed to Iroquois attacks in 1650, the Ottawa quickly filled the gap as suppliers. In addition to the external pressure imposed by the Iroquois, Huron society also underwent internal upheaval. The introduction of Christianity by the Jesuits probably contributed to divisions between converts and adherents to the traditional religion. In addition, Huron religion came under assault as traditional shamans and other practitioners proved unable to stem the disastrous effects of European diseases. This same pattern repeated itself again and again as whites progressed further west. When first contacted, Indian groups focused intensively on fur trapping as a specialized means of obtaining foreign materials. When the Indians exhausted their local supply they would attempt to maintain the trading structure by becoming middlemen or expanding their territorial control in an effort to tap new sources. The importance of Indian middlemen is reflected in the fact that at some Hudson's Bay Company forts, natives provided $70 \%$ of the furs traded (Ray and Freedman 1978).

Another persistent feature of this system throughout its history was the active encouragement whites provided. Europeans urged Indians to trap fur-bearing animals even at the expense of time that could have been used in traditional subsistence activities (Preston 1975). It is clear that whites depended on Indians whose talents in hunting, preparing pelts, and transporting the furs fueled the trade into the nineteenth century. This was especially true in the early years. Before 1630 there were only 100 Frenchmen in Canada on a permanent basis at any one time (Eccles 1969). These few men depended on the productive capacity of the natives to satisfy the large European demand. There was a similar reliance in New England. The fortunes of Plymouth were closely tied to furs, and the natives' ability to supply this commodity, from the inception of the colony (Moloney 1967). Indians recognized the value of their labor invested in producing furs and negotiated accordingly. To reiterate a point made above, I should note that while Native Americans and Europeans both thought out their involvement in the fur trade rationally, the two groups did focus on somewhat different economic aspects; Indians stressed the 
functional value of the commodities they acquired and used directly in their daily lives, while European traders focused on profit. The native perspective is evident in how they bartered to receive the best and most goods possible under various trade conditions. The yearly rendezvous at Tadoussac at the mouth of the Saguenay River during the 1500s witnessed the gathering of over 1000 Algonkian, Etchimin, and Montagnais. These people learned quickly not to barter their furs with the first European ship to arrive; instead, they waited for others in order to bid up the price (Eccles 1969). Traders' accounts are full of comments regarding the shrewd bargaining abilities of various native groups, who often played the Europeans against one another by threatening to take their furs elsewhere if not satisfactorily compensated (JR, 6:299, 66:173; Preston and Lamontagne 1958). In addition, Indians were not satisfied with substandard goods. The Huron complained about guns that exploded and injured the user, cheap thread that made poor netting, and kettles that were too thin and wore out quickly (de Lahontan 1905). Indians often refused to take any metal object in trade that had even the slightest crack since they knew from experience that such breaks would expand in the cold northern climate (Ray 1980). The natives were not beyond deceit either, as they occasionally tried to pass defective furs as being of higher quality (Crowe 1974).

A quick review of some figures gives an idea of the volume of the trade and thus the degree of importance fur-bearing animals came to have. Between 1620 and 1630 the French exported anywhere from 12,00 to 30,000 beaver skins a year to Europe (Trigger 1976). By the 1680s the amount had reached 140,000 pounds/annum (one skin=one pound) (Innis 1956). New England supplied an annual average of over 40,000 pelts in the late seventeenth century (Norton 1974). In the early nineteenth century Europe received up to 200,000 beaver skins a year from America (Chittenden 1902). In return for this plethora of furs, Indians received a wide range of products. In 1722-1723, three French forts along the Great Lakes supplied the following goods in exchange for 16,677 skins $(8,307,49.8 \%$, beaver): 1605 sewing needles, 632 catfish hooks, 273 men's shirts, 336 women's shirts, 214 children's shirts, 217 butcher knives, 2,109 other knives, 243 pounds of red and yellow copper cauldrons, 328 axes, 59 guns, 4,493 gun flints, 3,640 pounds of shot and balls, and 6,463 pounds of flour (Preston and Lamontagne 1958). Some of this material was used by the inhabitants of the forts, but most was passed on to the Indians. Other European goods involved in the trade included awls, hatchets, wool stockings, sewing thread, coarse white thread for nets, iron for arrowheads, glass beads, tobacco, soap, and sabers and cutlasses (de Lahontan 1905).

\section{IMPACT OF FUR PRODUCTION}

\section{Dependence on Trade Goods}

One important result of the tendency to specialize in fur production was an increasing dependence on European products and the trade system that developed as a means of attaining them (Kroeber 1939). Europeans made efforts to facilitate this process by establishing posts in strategic positions (Eccles 1969; JR, 66:69; Ray and Freedman 1978). Another factor that influenced the location of forts was European imperial rivalry, as the French attempted to restrict English access to the hinterland by setting up posts to maintain associations with Indians through trade, despite the saturated market in France (Eccles 1969, 1983) and the significant expense of providing gifts to native allies (Desbarats 1995) $)^{2}$. The technological superiority of certain European items supplied the initial impetus, eventually reaching the point of dependence by the natives on the imported materials; this situation upset the balance in economies that had previously been largely self-contained (Callender 1962). As early as

\footnotetext{
${ }^{2}$ Desbarats (1995:629-630) demonstrates that French officials in the colony and at home complained about outlays for native alliances, but while these were substantial, it would have cost much more to have a larger contingent of soldiers in Canada.
} 
1616, Indians in eastern Canada expressed their concern with maintaining the trade by offering to house Frenchmen whose fort had been destroyed by the British $(J R, 3: 71)$. By the 1630s the Huron had become dependent on European tools. Iron axes and hatchets enabled them to clear land more rapidly and allowed them to raise more corn which was exchanged for furs with their various native trading partners. Other metal cutting tools expedited a variety of manufacturing processes, thus freeing more time for trade. The Huron also required metal arrowheads which could pierce the wooden body armor used by their enemies the Iroquois. In addition, the Huron needed European trade goods to maintain the sophisticated system of intertribal alliances on which their security and prosperity rested (Trigger 1979). In 1647 the Huron, beleaguered by persistent Iroquois raids, undertook the hazardous journey to the French settlements under dangerous circumstances because of the need for hatchets, guns, ammunition, and other supplies $(J R, 32: 179)$.

A similar dependence on European products was evident among the Iroquois. By the 1630s this group used iron hinges, chains, harrows, hoops, and nails in house construction and other tasks. In the next decade guns, swords, axes, mallets, and clothing of European origin were also common in many Iroquois villages (Trigger 1976). The process of incorporation into the world-economy was well advanced, and it was from this point on that European traders were ascendant in relations with native trade partners.

This dependence on the fur trade had a number of repercussions for the Huron and other groups. By 1630 Huronia was essentially devoid of beaver because of excessive trapping. The Huron turned increasingly to the northern and western hunting groups to sustain the flow of furs, and encouraged this process by offering substantial amounts of French artifacts in return for furs. As a result, the hunters intensified their trapping and trading activities, and spent less time on fishing and hunting for subsistence. This led to an increasing reliance on agricultural peoples to make up the difference in foodstuffs. In eastern Canada, the Montagnais purchased much food from the French with a portion of their fur catch, but for other groups the Huron were a more reliable and cheaper source (Trigger 1976).

As a measure of the importance of obtaining European goods, there is the evidence of continued high levels of production and exchange even under adverse conditions. Between 1636 and 1640, approximately one-half of all Hurons perished in epidemics of diseases inadvertently introduced by the French. Despite this catastrophe, fur production increased in the 1640s. Trigger suggests this level of production required substantial organizational realignment. The Huron evidently encouraged Algonkian hunters to trap more beaver than before. This activity further undermined the traditional Algonkian subsistence base, but greater dependence on Huron beans and corn, probably a more secure means of alleviating starvation, balanced the situation. The Algonkian hunters may have been open to this change because of the loss of many skilled craftsmen in the epidemics, an event that made them dependent on European utensils they received from the Huron. For the latter group, more time had to be spent in clearing land and in cultivation. In addition, as a proportion of the remaining population, more men would have been involved in trading activities. When French trade goods could be substituted for traditional Huron products that required much time to make, the increasing demands of trade probably dictated that the foreign objects be adopted (Trigger 1976).

\section{Territorial Expansion}

The traffic in furs was a catalyst that exacerbated existing animosities between native groups and spurred aggressive expansionism. This was another consistent pattern in all the regions affected by the fur trade and arose out of the dependence on European goods discussed above. To assure the flow of goods, natives either had to control the production of furs or the system of dispersal. When home areas were trapped out, as happened early among the Huron and Iroquois, alternatives had to be found. In the eastern Great Lakes region, the increase in prehistoric populations due to agriculture triggered conflict well before whites arrived (Trigger 1982; Ritchie 1956). The advent of the fur trade added further fuel to an already volatile situation and enhanced the old rivalries. With their local sources exhausted, the 
Huron zealously protected their middleman role and blocked the efforts of western groups to trade directly with the French and also kept their sources secret from the Europeans (Eccles 1969; Tooker 1964).

The Iroquois resorted to a more overtly aggressive plan when their local fur supplies dwindled. Since they were surrounded by other horticultural people who had little need for their food material, they could not engage in middleman exchange to the same degree as the Huron. The Iroquois opted instead for fur piracy and territorial expansion. They raided Huron and Algonkian trading parties and carried off the furs to trade with the Dutch. Some scholars (Brandão 1997) argue that the Iroquois did not engage extensively in fur piracy, focusing instead on territorial expansion as the critical element. Expansion was primarily to the west in an effort to control hunting grounds in Ontario (Trigger 1976). The raiding to the north was successful in almost completely shutting down fur expeditions along the western St. Lawrence and forced Indians heading to French posts to take the more circuitous northern route $(J R, 40: 211)$. The Iroquois also blocked groups to their south and west from transporting pelts to the Dutch traders (Kenton 1925).

The French, Dutch, and English were all drawn into this intense rivalry. The Europeans were often obliged to join in military alliances with their native trading partners whose requests for aid they could not refuse if the flow of furs was to continue (Ray and Freedman 1978). Indians thus had a great part in determining the structure of the fur trade system.

Those native groups equipped with guns held a distinct military advantage in central Canada in the search for more fur territory. Guns upset the pre-contact balance of power. European weapons helped the Cree dominate the flow of furs into certain British posts. In their turn, the Chipewyan intruded on Cree lands in search of more beaver. In the late eighteenth to mid-nineteenth centuries the Blackfoot regulated the fur trade in the foothills of the Canadian Rockies, taking and defending new hunting grounds primarily on the basis of superior force provided by firearms. It became clear to many native groups that if they lacked furs, they could not obtain European materials and were at a disadvantage vis-a-vis traditional enemies who had such access (Crowe 1974; Gillespie 1975; Lewis 1942; Saum 1965).

\section{Changes in Social Structure}

The social structure of native societies also yielded to the rippling effects of the traffic in furs. Lewis (1942) describes the alteration of marriage patterns among the Blackfoot due to exposure to the fur trade. The increased burden of preparing skins and hides placed a greater demand on female labor and thus enhanced their economic importance. As a result, polygyny developed to a level unprecedented for the Plains. In the 1780s, most men had one or two wives, with a maximum of six. By the 1830s some wealthy chiefs had eight wives while in the next decade most men had three, many six to eight, and a few as many as twelve wives. Later in the century, some men had twenty to thirty spouses. The largest increase in wives occurred after 1833 and coincided with the burgeoning buffalo hide trade in Canada and the United States. Lewis envisions a circular system in operation. Guns obtained in the trade were used both to hunt and conduct raids for horses. By using horses to purchase wives, men converted idle capital (extra horses) into productive capital (wives). The women served to process more hides which went to the trading posts in exchange for guns and other commodities (Lewis 1942). The greater emphasis on bride price measured in horses led to changes in marrying ages. A report from 1787 indicated girls were married at sixteen to eighteen, men at twenty-two and older. By the late nineteenth century, girls married between ten and sixteen, and men rarely before thirty-five. Fathers wished to marry off their daughters as soon as possible to obtain the bride price. A man, however, was not considered an eligible son-in-law until he had accumulated sufficient property through hunting and warfare. Within the household, status differences and animosities between senior and junior wives intensified since the sororate lost force as an ameliorating influence (Lewis 1942). This situation is a prime example of the "commodity chain" that Dunaway argues exploits women. She contends that "the 
capitalist mode of production structures and reshapes households in ways that minimize production costs by allowing extensive use of conditions external to the production process" (Dunaway 2001:18).

Religious change also often accompanied Indian involvement in the fur trade. Indigenous foundation or creation myths described native groups as autochthonous, and provided an ordered universe. Some Indians considered the first Europeans they encountered to be supernatural beings, but they quickly came to see the strangers as humans (Trigger 1991). Active proselytizing by the French and English, combined with the devastation caused by epidemic diseases that native healers could not cure, undermined native beliefs and cosmology to some extent. In addition, some peoples adopted certain elements of Christianity into their native belief systems, creating an amalgam. The Europeans often used their particular brand of Christianity as another means of solidifying trading relationships. As noted above, the conversion of native communities at the outset was probably not complete, and thus set up internal divisions that festered. Various native societies adopted a cynical view, as indicated by the following quote by an Iroquois in 1711: "If the English sell goods cheaper than the French, we will have ministers; if the French sell them cheaper than the English, we will have priests" (Parkman 1892: I, 10). As the quote suggests, religion became one of the elements of negotiation.

\section{Effects on Animal Populations}

The greatest impact of this system was on the basic resources, i.e., the fur-bearing animals whose pelts were the Indians' products. A frequent observation by both contemporary eye-witnesses and modern scholars refers to the excessive hunting of furs by natives to meet European demand that resulted in the wanton annihilation of many species. This behavior is often held to be contrary to the prudent exploitation in aboriginal pre-contact times. (de Charlevoix 1761; J.C.B. 1941; Sandoz 1964; Crowe 1974; Axtell 1980) Martin attributes this change, from the traditional abstemious approach to a rampant profiteering at the expense of the environment, to the deterioration of an ecological ethos that supernatural sanctions had bolstered. The native religious beliefs and world view lost their hold on the Indian mind when shamans proved utterly incapable of checking the ravages of epidemic diseases. With this traditional underpinning removed, there was no longer the fear of violating hunting taboos that regulated the amount of game that could be taken; a wholesale slaughter of animals for their furs ensued (Martin 1978).

Although this explanation is useful in comprehending some aspects of the problem, its ideational orientation is not open to empirical examination. On the other hand, economic motives can be found in the ethnohistoric record; it seems more likely that the desire for trade overrode the traditional conservation ethic, as Axtell (1980) posits. Natives did not abandon but rather amended hunting taboos due to the material conditions of a new economic reality, and this change may have been a contributing factor in the subsequent decimation of animal populations.

\section{CONCLUSION}

This study suggests that people who live in peripheries or margins can and do determine the nature and extent of interaction with core polities to at least some degree. Certainly, states can impose their will in some instances. However, as Hall (1999: 14) points out, "complete assimilation was almost never a goal" of premodern states in their interaction with other societies. Indeed, the analysis of such events loses much if influence is viewed as unidirectional; we must consider people in the periphery as active players. As a result, peripheral groups often retained a distinct identity even as they selectively adopted certain outside features. What I believe is clear in the ethnohistoric and archaeological records is that people on both sides of a cultural divide manage their resources in ways that they believe will benefit them best. The process involves a series of decisions about what to offer, when, and how. Individuals determine if the proposed exchange is to their advantage; rejection typically entails counteroffers, which 
by definition is negotiation, the effort to get a better deal. The process is fluid rather than monolithic, often requiring a number of intermediate offers and counters (i.e., haggling), until an agreement is reached. The negotiation has to leave each participant sufficiently gratified so as to provide grounds for future transactions. While this general process is universal, I argue, variations do appear in different places and times because what people value may range broadly, from material objects such as furs, kettles, and foodstuffs, to nonmaterial elements such as prestige and status. The exact nature of what is exchanged may vary by place and time, but the process is universal because by default it requires negotiation. Peripheries are primary venues of negotiation because it is at these critical nodes that there is the greatest potential for two groups to acquire some things that their respective home ranges lack. Although no culture is ever entirely integrated or homogeneous, in peripheries societies that are more different than alike come into contact and the encounters act as catalysts for innovation. As Hall has noted, these peripheries or contact zones are like permeable membranes, through which certain things pass in both directions. In population genetics, the mating that occurs at the intersection of demes or breeding populations increases the size and variation of the gene pool. Variation is the very lifeblood of evolution, since it provides the material on which natural selection acts. The new forms may then influence the future direction of each deme if the interbreeding provides more adaptive individuals who then take their respective groups in new directions. So, innovation can often flow from the edges into the center. Continuing with the organic analogy introduced at the beginning of this study, it is thus at peripheries that culture change is most likely to occur, with significant ramifications for the respective groups. Incorporation, then, is a more comprehensive phenomenon, as Hall (1989) and others have argued.

In Cyprus, the nature of negotiation, and thus the degree of incorporation, varied over time. Initially, the Malloura Valley was exploited by early farmers only as a source of raw material for the production of basic tools necessary for a wide range of tasks. This use of local chert was probably one reason that Cyprus developed its own unique Neolithic culture. There was certainly contact with Anatolia and the Levant, since both the suite of domesticated species and the farmers themselves originated from the mainland, but Cyprus developed its own unique forms in various things from architecture to stone tool assemblages. It seems the people of the Malloura Valley and surrounding regions, and to a significant extent the whole island, modified portions of the Neolithic lifestyle to fit their particular interests. The fact that there is very little imported Anatolian obsidian on Cyprus in the Neolithic, while such material is widespread in the Levant, suggests early farmers on the island satisfied demand for a critical resource locally; this gave them the freedom to accept or reject other mainland traits. Later in time, the process of incorporation involved differential acquisition and display of religious symbolism by elites, and shifts in agricultural strategies by farmers to take advantage of certain opportunities. The material from the sanctuary and tombs starting in the Archaic period provides clear indication of culture contact that is both insular and international in nature, especially noticeable in artistic motifs that demonstrate connections with the Phoenician Levant, Pharaonic Egypt, and the Hellenized Aegean. The Malloura residents adopted certain elements from each area, creating a unique mixture of cultural elements that reflects the cultural variability available at such contact zones. In other periods, major empires intruded on Cyprus, and incorporation took on a more overtly exploitative form. In such times, negotiation could take the form of resistance; for example, despite the long periods of foreign domination of the central political system by the Venetians, Franks, Ottomans, and British, Cypriots largely retained their allegiance to Orthodox Christianity as a key element of national identity, while adopting certain features of the hegemonic culture, from a variety of Turkish words to the English practice of driving on the left side of the road.

In the North American fur trade, natives accommodated rapidly to the demands of a capitalist market economy. This action involved economic specialization in both production and distribution, by way of a series of conscious choices made after balancing what the Native Americans viewed as the appropriate available options. The Basque and French whalers and fishermen who made first contact with native peoples in the area around Newfoundland and the St. Lawrence region brought the products 
of European metal technology to the New World. Indians immediately saw the value of these objects and made concerted efforts to acquire the objects, both utilitarian and decorative. In this process, the Native Americans bargained actively to obtain the optimum terms - they could and did accept certain things and reject others. In the sixteenth and well into the seventeenth century, Indians often held the upper hand since it was they who provided the furs that Europeans valued so highly. As a result, they had a means by which to obtain objects they desired, to augment existing alliances or build new ones, or to enhance status, and negotiated with the Europeans accordingly. Both sides in these transactions operated in a rational manner to maximize their respective interests at the least cost. While the specific economic interests of the Native Americans and Europeans were somewhat different (functional utility vs. capitalist profit, respectively), the interchanges shared the essential character of economizing behavior. Neither side foresaw the long-term consequences of these interactions. The ability of European capitalist states to marshall technical resources and manpower, plus the diminished numbers of indigenous people in North America due to epidemic diseases (see Diamond 1997), eventually overwhelmed Indian societies and gave them less leverage in their interaction with the intruders. However, that ability to negotiate remained an important feature of Indian-white relations into the nineteenth century. Furthermore, the process of incorporation varied for different groups such as the Huron and Iroquois, in part due to how they arbitrated their involvement with various European groups. In terms of Chase-Dunn and Hall's (1997:61-64) continuum, incorporation proceeded from weak to strong over a period of four centuries. I would supplement that model with the element of negotiation, which for indigenous peoples in the Americas went from strong to weak over that same span.

The great utility of world-systems theory is its ability to highlight critical patterns of interaction between cultures. In so doing, the approach allows us to focus on the fundamental similarities that all peoples share across time and space. Such generalization facilitates interdisciplinary research that draws on information from various fields. In the present study, I make use of archaeological, ethnohistoric, and historical data to trace the evolution of cultural interaction at peripheries, with a special focus on negotiation. The course of incorporation followed roughly similar trajectories in Cyprus and eastern North America. In both cases, the people in the peripheries exercised some level of control in managing their relationship with the outside world. The guiding principle in each place over time was the effort to extract maximum benefit in dealing with outside groups. What the case studies indicate is that, to paraphrase a business ad in a magazine, in cultural interactions, you don't get what you deserve, you get what you negotiate.

Acknowledgements: I thank Michael Toumazou, Director of the Athienou Archaeological Project (AAP) for permission to use the photographs in Figures 4 and 5, and Derek Counts, Associate Director of the AAP, for preparing Figures 1 and 4. Andrew Womack helped with various aspects of manuscript and figure preparation. I am grateful for a number of helpful comments on an earlier draft by an anonymous reviewer; I adopted most of those suggestions, but am alone responsible for any errors that may remain.

\section{REFERENCES}

Allen, Mitchell. 1996. Contested Peripheries: Philistia in the Neo-Assyrian World-System. Unpublished Ph.D. dissertation. University of California, Los Angeles.

Axtell, James. 1980. The Indian People of Eastern America. New York: University of Oxford Press.

B., J.C. 1941. Travels in New France. Edited by Sylvester K. Stevens, Donald H. Kent, and Emma E. Woods. Harrisburg: Pennsylvannia Historical Commission.

Barth, Frederik. 1959. Political Leadership among Swat Pathans. London: Athlone.

Binford, Lewis R. 1980. "Willow Smoke and Dogs' Tails: Hunter-Gatherer Settlement Systems and Archaeological Site Formation." American Antiquity 45:4-20. 
Brandão, José António. 1997. "Your Fyre Shall Burn No More”: Iroquois Policy toward New France and Its Native Allies to 1701. Lincoln: University of Nebraska Press.

Callender, Charles. 1962. Social Organization of the Central Algonkian Indians. Milwaukee Public Museum Publications in Anthropology No. 7. Milwaukee: Milwaukee Public Museum.

Carlson, Jon D. 2001. "Broadening and Deepening: Systemic Expansion, Incorporation and the Zone of Ignorance.” Journal of World-Systems Research 7(2): 225-263.

. 2002. "The 'Otter-Man' Empires: The Pacific Fur Trade, Incorporation and the Zone of Ignorance." Journal of World-Systems Research 8(3): 390-442.

Chase-Dunn, Christopher, and Thomas D. Hall. 1997. Rise and Demise: Comparing World-Systems. Boulder: Westview.

Chase-Dunn, Christopher, and Kelly M. Mann. 1998. The Wintu and Their Neighbors: A Very Small World-System in Northern California. Tucson: University of Arizona Press.

Chittenden, Hiram Martin. 1902. The American Fur Trade of the Far West. New York: Francis Harper.

Cline, Eric H. 2000. "“Contested Peripheries' in World Systems Theory: Megiddo and the Jezreel Valley as a Test Case." Journal of World Systems Research 6(1):7-16.

Craik, Brian. 1975. "Fur Trapping and Food Sharing in Fort George, Quebec." Pp. 223-236 in Papers of the Sixth Algonquian Conference, 1975. Canadian Ethnology Service Paper No. 23. Ottawa: Canadian Ethnology Service.

Crowe, Keith J. 1974. A History of the Original Peoples of Northern Canada. Montreal: McGillQueen's University Press.

Danziger, Edmund J. 1978. The Chippewas of Lake Superior. Norman: University of Oklahoma Press.

de Charlevoix, Pierre. 1761. Journal of a Voyage to North America. Translated from French. London: R. and J. Dodsley.

de Lahontan, Baron. 1905. New Voyages to North America. Edited by Reuben G. Thwaites from the 1703 English edition. Chicago: A.C. McClurg.

Desbarats, Catherine M. 1995. "The Cost of Early Canada's Native Alliances: Reality and Scarcity's Rhetoric." William and Mary Quarterly 3rd ser. 52(4):609-630.

Diamond, Jared. 1997. Guns, Germs, and Steel: The Fates of Human Societies. New York: W. W. Norton.

Dothan, T., and A. Ben-Tor. 1983. Excavations at Athienou, Cyprus, 1971-1972. Jerusalem: Hebrew University.

Drews, Robert. 1993. The End of the Bronze Age: Changes in Warfare and the Catastrophe ca. 1200 B.C. Princeton: Princeton University Press.

Dunaway, Wilma A. 2001. "The Double Register of History: Situating the Forgotten Woman and Her Household in Capitalist Commodity Chains." Journal of World-Systems Research 7(1):2-29.

Eccles, W.J. 1969. The Canadian Frontier 1534-1760. New York: Holt, Rinehart, and Winston. . 1983. "The Fur Trade and Eighteenth-Century Imperialism." William and Mary Quarterly 3rd ser. 40(3): 341-362.

Ewers, John C. 1972. "Influence of the Fur Trade on Indians of the Northern Plains.” Pp. 1-26 in People and Pelts, edited by Malvina Bolus. Winnipeg: Pequis Publishing.

Francis, Daniel, and Toby Morantz. 1983. Partners in Furs. A History of the Fur Trade in Eastern James Bay 1600-1870. Montreal: McGill-Queen's University Press.

Futuyma, Douglas J. 1986. Evolutionary Biology. $2^{\text {nd }}$ edition. Sunderland, MA: Sinauer.

Gillespie, Bery C. 1975. Territorial Expansion of the Chipewyan in the $18^{\text {th }}$ Century. Proceedings of the Northern Athabaskan Conference, 1971, Vol. 2. Publication No. 27. Ottawa: Canadian Ethnology Service.

Griffin, James B. 1967. "Eastern North American Archaeology: A Summary.” Science 156:175-191.

Guilaine, J., F. Briois, J. Coularou, and I. Carrere. 1995. "L'établissement Néolithique de Shillourokambos (Parekklisha, Chypre). Premiers résultats." Report to the Department of Antiquities, Cyprus 1995:11-31. 
Hall, Thomas D. 1986. "Incorporation in the World-System: Toward a Critique.” American Sociological Review 51: 390-402.

1989. Social Change in the Southwest, 1350-1880. Lawrence: University Press of Kansas. . 1999. "Civilizational Incorporation of Indigenes: Toward a Comparative Perspective." Comparative Civilizations Review 39: 10-27.

Heidenreich, Conrad. 1971. Huronia. A History and Geography of the Huron Indians 1600-1650. Montreal: McClelland and Stewart.

Homans, George. 1958. "Social Behavior as Exchange." American Journal of Sociology 62: 597-606.

Innis, Harold A. 1956. The Fur Trade in Canada. Toronto: University of Toronto Press.

Kardulias, P.Nick. 1999. Preface. Pp. xvii-xxi in World-Systems Theory in Practice: Leadership, Production, and Exchange, edited by P. Nick Kardulias. Boulder: Rowman and Littlefield.

Kardulias, P. Nick, and Richard W. Yerkes. 1996. "Microwear and Metric Analysis of Threshing Sledge Flints from Greece and Cyprus." Journal of Archaeological Science 23:657-666. 1998. "Defining the Cypriot Aceramic Neolithic: The Lithic Evidence." Lithic Technology 23:124-138.

Kehoe, Alice B. 1992. North American Indians. A Comprehensive Account. $2^{\text {nd }}$ edition. Englewood Cliffs, NJ: Prentice Hall.

Kenton, Edna, ed. 1925. The Jesuit Relations and Allied Documents. New York: Albert and Charles Boni.

Knapp, A. Bernard. 1988. "Ideology, Archaeology and Polity." Man 23:133-163.

Knapp, A. Bernard, and Michael Given. 1996. "The Sydney Cyprus Survey Project (SCSP)-Third Season (1995)." Report to the Department of Antiquities, Cyprus 1996:295-366.

Kroeber, Alfred L. 1939. Cultural and Natural Areas of Native North America. Berkeley: University of California Press.

Lawson, Murray G. 1972. “The Beaver Hat and the North American Fur Trade.” Pp. 27-37 in People and Pelts, edited by Malvina Bolus. Winnipeg: Pequis Publishing.

Lewis, Oscar. 1942. The Effects of White Contact Upon Blackfoot Culture with Special Reference to the Role of the Fur Trade. Monograph No. 6. Washington: American Ethnological Society.

Marquette, Jacques. 1966. Voyages of Marquette in the Jesuit Relations. Ann Arbor: University Microfilms.

Martin, Calvin. 1978. Keepers of the Game. Berkeley: University of California Press.

Mason, Otis T. 1891. "Aboriginal Skin Dressing - A Study Based on Material in the U.S. National Museum." P. 568 in Report of the National Museum 1891.

Mbakalakis, Georgios. 1988. Anaskafi sto Lofo Giorkous. Athens: Athens Archaeological Society.

Milner, George R. 2004. The Moundbuilders. Ancient Peoples of Eastern North America. London: Thames and Hudson.

Moloney, Francis X. 1967. The Fur Trade in New England 1620-1676. Hamden: Anchor Books.

Morris, Ian. 1999. "Negotiated Peripherality in Iron Age Greece: Accepting and Resisting the East." Pp. 63-84 in World-Systems Theory in Practice: Leadership, Production, and Exchange, edited by P. Nick Kardulias. Boulder: Rowman and Littlefield.

Murphy, Robert F., and Julian H. Steward. 1968. "Tappers and Trappers: Parallel Process in Acculturation.” Pp. 214-233 in Man in Adaptation-The Cultural Present, edited by Yehudi A. Cohen. Chicago: Aldine Press.

Norton, Thomas E. 1974. The Fur Trade in Colonial New York. Madison: Univerisity of Wisconsin Press.

Oakes, Maud. 1969. The Two Crosses of Todos Santos: Survivals of Mayan Religious Ritual. Princeton: Princeton University Press.

Park, Michael. 2002. Biological Anthropology. $3^{\text {rd }}$ edition. Mountain View, CA: Mayfield. Parkman, Francis. 1892. A Half-Century of Conflict. 2 vols. Boston: Little, Brown, and Co.

Peale, Titian R. 1872. "On the Uses of the Brain and Marrow of Animals among the Indians of 


\section{JOURNAL OF WORLD-SYSTEMS RESEARCH}

North America." Annual Report of the Smithsonian Institution 1872:390-391.

Preston, Richard. 1975. "Eastern Cree Community in Relation to Fur Trade Post in the 1830s: The Background of the Posting Process." Papers of the Sixth Algonquian Conference, 1974, Paper No. 23. Ottawa: Canadian Ethnological Service.

Preston, Richard, and Leopold Lamontagne. 1958. Royal Fort Frontenac. Toronto: University of Toronto Press.

Ray, Arthur. 1980. "Indians as Consumers in the 18th Century." Pp. 255-271 in Old Trails and New Directions: Papers of the 3rd North American Fur Trade Conference, edited by Carol M. Judd and Arthur J. Ray. Toronto: University of Toronto Press.

Ray, Arthur, and Donald B. Freeman. 1978. "Give Us Good Measure": An Economic Analysis of Relations between the Indians and the Hudson's Bay Company before 1763. Toronto: University of Toronto Press.

Richter, Daniel K. 1983. "War and Culture: The Iroquois Experience." William and Mary Quarterly 40(4):528-559.

Ritchie, William A. 1956. "Prehistoric Settlement Patterns in Northeastern North America." Pp $72-84$ in Prehistoric Patterns of the New World, edited by Gordon R. Willey. Viking Fund Publications in Anthropology No. 23. New York: Wenner Gren Foundation.

Robinson, H. M. 1879. The Great Fur Land. London: Sampson Low, Marston, Searle, and Rivington.

Sandoz, Mari. 1964. The Beaver Men. New York: Hastings House.

Saum, Lewis O. 1965. The Fur Trader and the Indian. Seattle: University of Washington Press.

Schortman, Edward. M., and Patricia A. Urban. 1994. "Living on the Edge: Core/Periphery Relations in Ancient Southeastern Mesoamerica." Current Anthropology 35:401-430. . 1999. "Thoughts on the Periphery: The Ideological Consequences of Core/Periphery Relations." Pp. 125-152 in World-Systems Theory in Practice: Leadership, Production, and Exchange, edited by P.Nick Kardulias. Boulder: Rowman and Littlefield

Shufeldt, R.W. 1889. "The Navajo Tanner.” Proceedings of the U.S. National Museum 11: 59-66.

Starna, William A., and José António Brandão. 2004. "From the Mohawk-Mahican War to the Beaver Wars: Questioning the Pattern." Ethnohistory 51(4):725-750.

Stein, Gil J. 1999. Rethinking World-Systems: Diasporas, Colonies, and Interaction in Uruk Mesopotamia. Tucson: University of Arizona Press.

Tooker, Elisabeth. 1964. An Ethnography of the Huron Indians, 1615-1649. Washington: Bureau of American Ethnology.

Toumazou, Michael K., Richard W. Yerkes, and P. Nick Kardulias. 1998. "Athienou Archaeological Project: Interim Report of Investigations in the Malloura Valley, Cyprus, 1990-95." Journal of Field Archaeology 25:163-182.

Trigger, Bruce G. 1969. The Huron, Farmers of the North. New York: Holt, Rinehart, and Winston. . 1976. The Children of Aataentsic, 2 vol. Montreal: McGill-Queen's University Press. . 1979. "Sixteenth Century Ontario: History, Ethnohistory, and Archaeology." Ontario History 71:205-223. . 1982. "Indians and Ontario's History." Ontario History 74:246-257.

. 1985. Natives and Newcomers: Canada's 'Heroic Age' Reconsidered. Montreal \& Kingston, ON: McGill-Queen's University Press. . 1991. "Early Native North American Responses to European Contact: Romantic versus Rationalistic Interpretations." Journal of American History 77(4): 1195-1215.

Turgeon, Laurier. 1998. "French Fishers, Fur Traders, and Amerindians during the Sixteenth Century: History and Archaeology." William and Mary Quarterly 3rd ser. 55(4):585-610.

Vandiveer, Clarence. 1929. The Fur-Trade and Early Western Exploration. Cleveland: Arthur H. Clark. Wallerstein, Immanuel. 1974. The Modern World-System I: Capitalist Agriculture and the Origins of the European World-Economy in the Sixteenth Century. New York: Academic Press. 
Wintemberg, W. J. 1942. "The Geographic Distribution of Aboriginal Pottery in Canada." American Antiquity 8:129-141.

Wright, J. V. 1972. Ontario Prehistory, an Eleven-Thousand-Year Archaeological Outline. Ottawa: National Museum of Man.

Yerkes, Richard W. 2000. "Ethnoarchaeology in Central Cyprus: Interdisciplinary Studies of Ancient Population and Agriculture by the Athienou Archaeological Project." Near Eastern Archaeology 63(1):20-34. 